\title{
Angiosperm Production of Three Virginia Marshes in Various Salinity and Soil Nutrient Regimes
}

Irving Avrum Mendelssohn

College of William and Mary - Virginia Institute of Marine Science

Follow this and additional works at: https://scholarworks.wm.edu/etd

Part of the Ecology and Evolutionary Biology Commons

\section{Recommended Citation}

Mendelssohn, Irving Avrum, "Angiosperm Production of Three Virginia Marshes in Various Salinity and Soil Nutrient Regimes" (1973). Dissertations, Theses, and Masters Projects. Paper 1539617449.

https://dx.doi.org/doi:10.25773/v5-n8a1-k768

This Thesis is brought to you for free and open access by the Theses, Dissertations, \& Master Projects at W\&M ScholarWorks. It has been accepted for inclusion in Dissertations, Theses, and Masters Projects by an authorized administrator of W\&M ScholarWorks. For more information, please contact scholarworks@wm.edu. 


\title{
ANGIOSPERM PRODUCTION OF THREE VIRGINIA \\ MARSHES IN VARIOUS SALINITY \\ AND SOIL NUTRIENT REGIMFS
}

\begin{abstract}
A Thesis
Presented To

The Faculty of the School of Marine Science

The College of William and Mary in Virginia
\end{abstract}

\author{
In Partial Fulfillment \\ Of the Requirements for the Degree of \\ Master of Arts
}

By

Irving A. Mendelssohn

1973 
APPROVAL SHEET

This thesis is submitted in partial fulfillment of the requirements for the degree of

Master of Arts

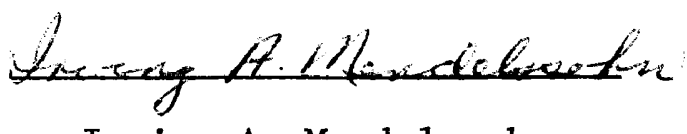

Irving A. Mendelssohn

Approved, August 1973

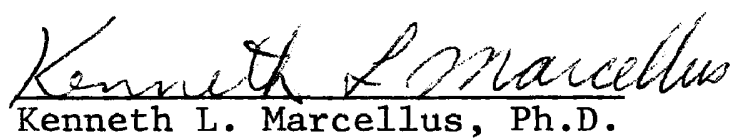

Kenneth L. Marcellus, Ph.D.
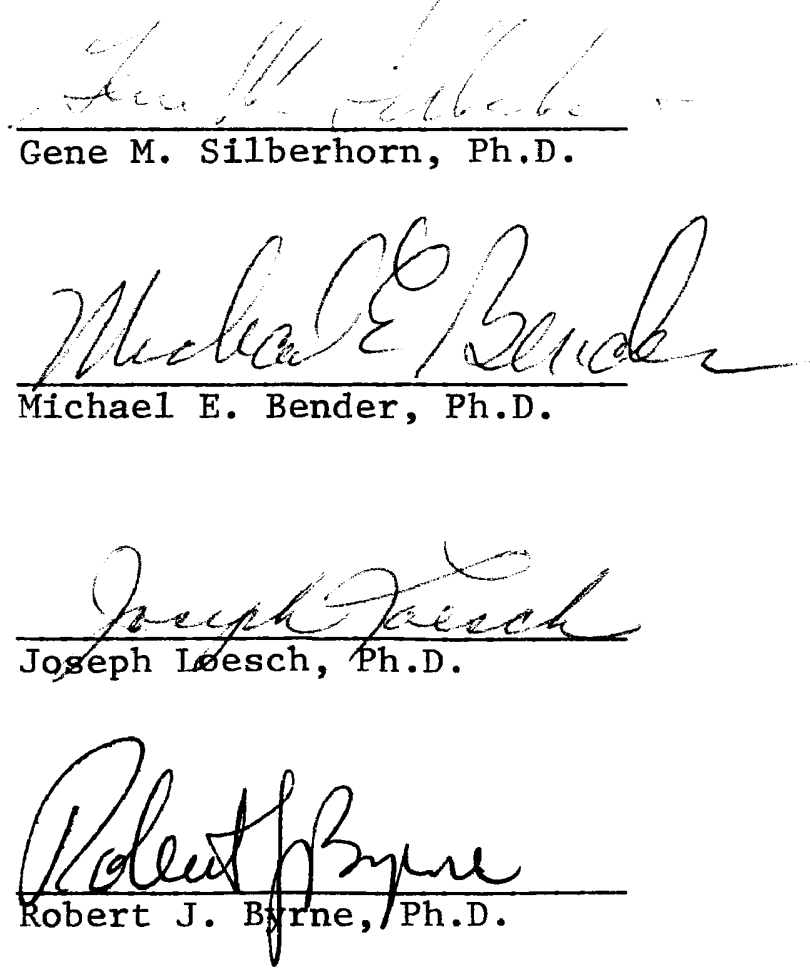

ii 
TABLE OF CONTENTS

Page

ACKNOWLEDGMENTS ............................ vi

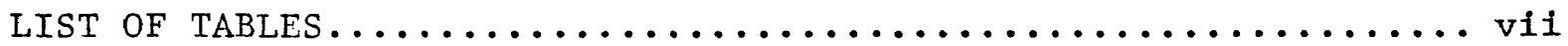

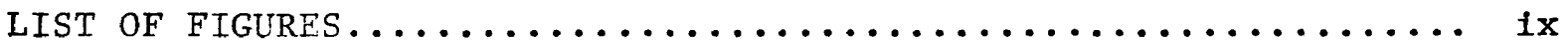

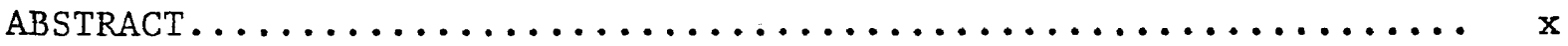

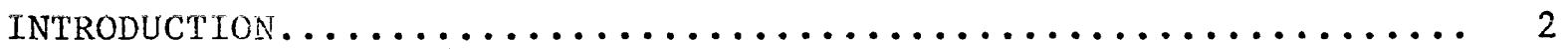

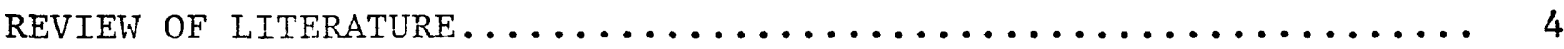

Marsh Productivity Studies...................... 4

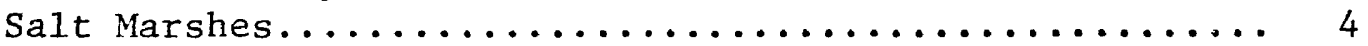

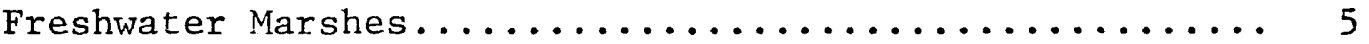

Soil Parameters and Marsh Productivity.............. 6

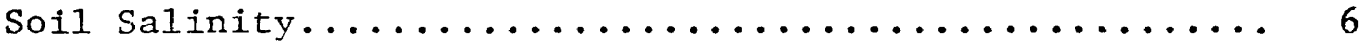

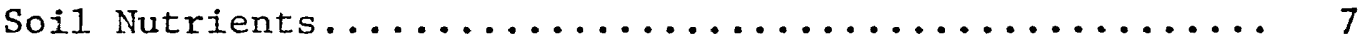

Marsh Plant Nutrients and Environmental Concentrations.... 8

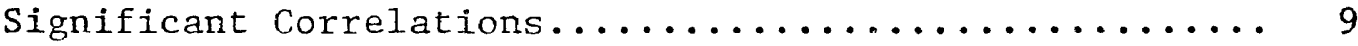

Non-Significant Correlations.................... 9

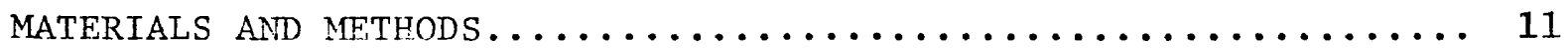

Determination of Primary Production............... 11

Soil Analysis............................. 15

Plant Tissue Analysis...................... 16

Data Analysis................................... 17

Sorenson's Index and Cluster Analysis............. 17

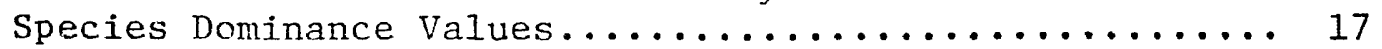

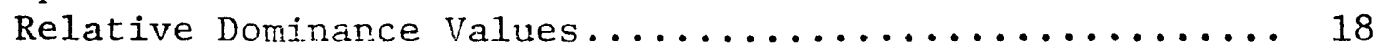

Analyses of Variance, Student-Newman-Keuls' Multiple 18

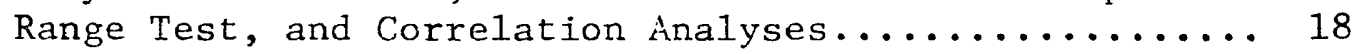

Multiple Regression......................... 19 
Community Composition......................... 20

Species Association......................... 20

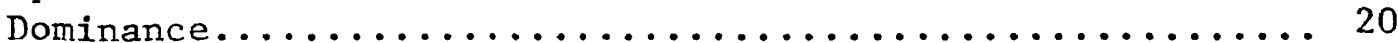

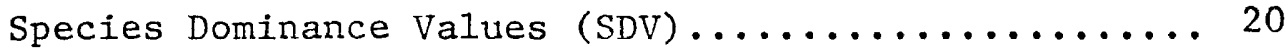

Relative Dominance Values (RDV).............. 30

Angiosperm Primary Production...................... 30

Net Annual Primary Production................... 30

Seasonal Trends............................. 30

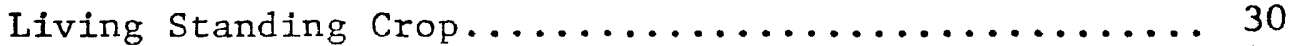

Dead versus Living Standing Crop.............. 42

Living to Dead Standing Crop Ratio............. 42

Marsh Soil Parameters......................... 42

Mean Concentrations......................... 42

Correlation between Soil Parameters............... 48

Soil TKN/TP Ratios......................... 48

Variations During the Growing Season............... 48

Nitrogen and Phosphorus Concentrations in Spartina 59

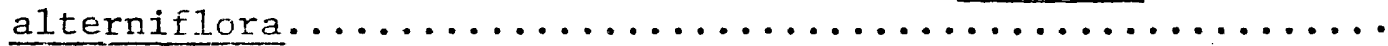

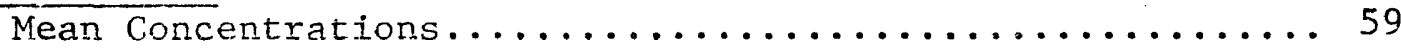

Spartina alterniflora TKN/TP Ratios.............. 59

Variations During the Growing Season................ 59

Relationship Between S. alterniflora TKN and TP

Concentrations and Soil Levels................ 63

Soil Parameters and Standing Crop................. 63

DISCUSSION................................ 68

Community Composition and Salinity............... 68

Annual Salt Marsh Primary Production................. 69

The Production of Virginia Marshes................. 69

The Growing Season of Fresh versus Salt Marshes.......... 70

Dead Standing Crop as a Nutrient Source.............. 73

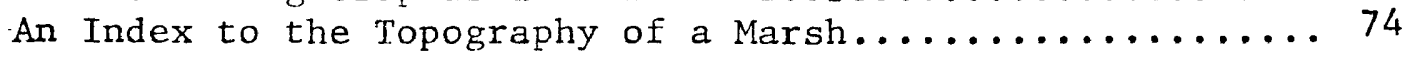

Soil Nutrient Concentrations Along a Salinity Gradient...... 74 
Marsh Plant Nutrient and Environmental Concentrations....... 77

Seasonal Variation.......................... 77

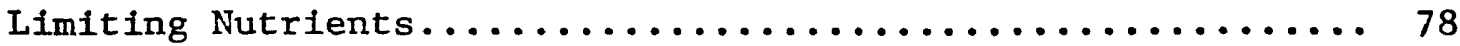

Correlation between Plant and Environmental Nutrient

Levels.................................. 79

Marsh Standing Crop Relative to Salinity and Soil Nutrients.... 79

APPENDIX ....................................... 82

LITERATURE CITED..................................... 94

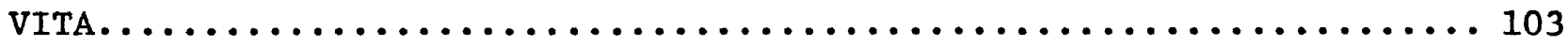




\section{ACKNOWLEDGMENTS}

The author wishes to express his sincere appreciation to Dr. Kenneth L. Marcellus for his encouragement and guidance throughout this study. Thanks are also extended to Drs. Gene Silberhorn, Michael Bender, Robert Byrne, and Joseph Loesch for critically reviewing the manuscript.

The author also wishes to thank the staff of the Ecology-Pollution Department of the Virginia Institute of Marine Science and Miss Sue Shirey for their aid and advice concerning the laboratory analyses used in this study. Deepest appreciation is extended to Mr. James Mercer, whose physical assistance and informative counsel made this study possible. Thanks are also extended to Ann Tyska for typing the final manuscript and the VIMS drafting department for preparing the figures.

Financial support was provided by the Research Applied to National Needs program of the National Science Foundation through a grant to the Chesapeake Research Consortium, Inc. 


\section{LIST OF TABLES}

Table

Page

1. Marsh Plant Species Found in Ware Creek, Carter Creek, and Wachapreague Marshes....................... 21

2. Associations in Ware and Carter Creek Marshes........... 25

3. Relative Dominance Values of Various Marsh Plant Species in Ware Creek, Carter Creek, and Wachapreague Marshes...... 35

4. Calculation of Net Primary Production of Ware Creek Marshes

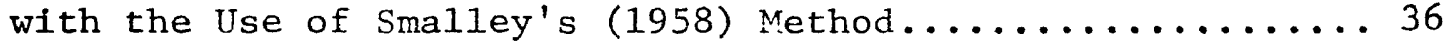

5. Calculation of Net Primary Production of Carter Creek Marsh

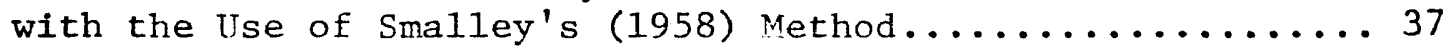

6. Calculation of Net Primary Production of Wachapreague Marsh with the Use of Smalley's (1958) Method............... 38

7. Salinity, Dominant Species, and Productivity of Vare Creek, Carter Creek, and Wachapreague Marshes............... 39

8. Mean Value of Soil Variables from Ware Creek, Carter Creek and Wachapreague Marshes $(\bar{X} \pm 1 S E) \ldots \ldots \ldots \ldots \ldots \ldots \ldots \ldots 47$

9. Correlation Matrix of Soil Parameters and Standing Crop in Ware Creek Marsh During the Period of Peak Standing Crop ... 49

10. Correlation Matrix of Soil Parameters and Standing Crop in Carter Creek Marsh During the Period of Peak Standing Crop.. 50

11. Correlation Matrix of Soil Parameters and Standing Crop in Wachapreague Marsh During the Period of Peak Standing Crop.. 51

12. Correlation Matrix of Soil Parameters and Standing Crop in the Three Marshes Combined During their Periods of Peak

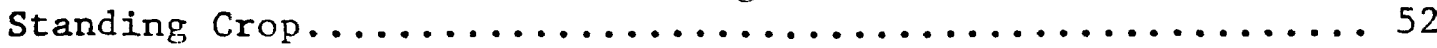

13. Mean Spartina alterniflora Total Kjeldah1 Nitrogen and Total Phosphorus Concentration During Peak Standing Crop $(\overline{\mathrm{X}} \pm 1 \mathrm{SE})$

14. Multiple Regression of Peak Standing Crop on Soil Parameters In Ware Creek Marsh.......................... 64 
15. Multiple Regression of Peak Standing Crop on Soil

Parameters in Carter Creek Marsh.................. 65

16. Multiple Regression of Peak Standing Crop on Soil

Parameters in Wachapreague Creek Marsh.............. 66

17. Multiple Regression of Peak Standing Crop on Soil

Parameters in Ware, Carter, and Wachapreague Marshes

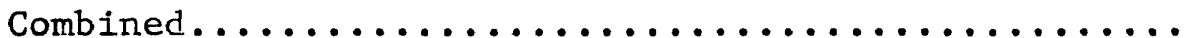

18. Comparison of Angiosperm Production Values of Some

Eastern United States Salt Marshes................ 71

19. Comparison of Soil Parameters from Three Different

Localities.............................. 76 


\section{LIST OF FIGURES}

Figure

1. Location of the Ware Creek, Carter Creek, and Wachapreague

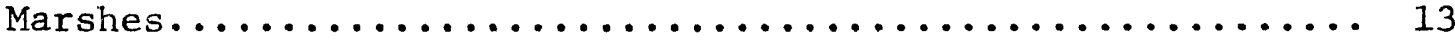

2. Dendrogram of species associations in Ware Creek Marsh..... 24

3. Dendrogram of species associations in Carter Creek Marsh.... 27

4. Species dominance values for various marsh plant species in Ware Creek Marsh............................ 29

5. Species dominance values for various marsh plant species in Carter Creek Marsh......................... 32

6. Species dominance values for species in Wachapreague Marsh.. 34

7. Seasonal changes in living standing crop from Ware Creek, Carter Creek, and Wachapreague Marshes............... 41

8. Comparison of living and dead standing crop in Ware Creek, Carter Creek, and Wachapreague Marshes................ 44

9. Seasonal changes in the living to dead standing crop ratio in Wachapreague, Carter Creek, and Ware Creek Marshes...... 46

10. Variation in selected soil and environmental parameters in Ware Creek Marsh during the growing season............. 54

11. Variation in selected soil and environmental parameters in Carter Creek Marsh during the growing season........... 56

12. Variation in selected soil and environmental parameters in Wachapreague Marsh during the growing season........... 58

13. Variation in total Kjeldahl nitrogen and total phosphorus of Spartina alterniflora in Wachapreague Marsh........... 62 


\begin{abstract}
The net angiosperm primary production and salinity and soil nutrient regimes of three Virginia marshes were determined. Oligohaline Ware Creek Marsh and mesohaline Carter Creek Marsh were most productive, $563 \mathrm{~g} / \mathrm{m}^{2} \mathrm{yr}$ and $572 \mathrm{~g} / \mathrm{m}^{2} \mathrm{yr}$, respectively, while euhaline Wachapreague Marsh was least productive, 362 $\mathrm{g} / \mathrm{m}^{2} \mathrm{yr}$. Species in Carter and Ware Creek Marshes were clustered into associations based on their salinity tolerance.

Soil nutrient concentrations were variable, and trends during the growing season were difficult to delineate. Nitrogen and phosphorus concentrations of Spartina alterniflora tissue were high in the spring and decreased as the growing season continued. No significant correlations were found between soil and plant nutrient concentrations, and a multiple regression of standing crop on soil $\mathrm{N}, \mathrm{P}, \mathrm{Mg}, \mathrm{K}, \mathrm{Ca}, \mathrm{pH}$, and salinity failed to delineate any of these parameters as the primary factors limiting salt marsh production.
\end{abstract}


ANGIOSPERM PRODUCTION OF THREE VIRGINIA MARSHES

IN VARIOUS SALINITY AND SOIL NUTRIENT REGIMES 


\section{INTRODUCTION}

Ever since the realization that estuarine marshlands are among the most productive ecosystems in the world (Odum, 1961) and that the biomass produced by these systems may be utilized directly or indirectly by a number of estuarine organisms (Fox, 1950; Darne11, 1961; Darne11, 1964; Adams and Angelovic, 1970; Odum, 1970), considerable time and effort has been directed toward the ecological investigation of these communities.

While the majority of initial research interests have centered on the descriptive ecology and productivity of salt marshes (see REVIEW OF LITERATURE), studies investigating the essential factors limiting salt marsh macrophytic production have been almost totally neglected. Some of the parameters which most probably govern this production are: 1) submergence, 2) marsh physiography, 3) climatic conditions, 4) salinity, and 5) soil nutrient concentrations.

One of these factors that has been intensively studied is salinity. Laboratory findings have determined that salt marsh plants can grow (Gosselink, 1970; Phleger, 1971) and germinate (Mooring et al., 1971) better in freshwater than saltwater. This suggests that these plants are facultative halophytes, invading the freshwater-brackish environment when possible and having a greater productivity in this habitat. 
However, there is relatively little field data to substantiate this theory (Harshberger, 1911; Berenyi, 1966).

One important area which has not been thoroughly investigated, other than through fertilizer experiments, is the effect of soil nutrients on marsh production. Ranwell (1964) sampled soil nutrients in Great Britain and found marsh grass production to be independent of soil nutrient concentrations. However, other studies have found nutrients to be limiting to marsh production. Boyd and Hess (1970) hypothesized that phosphorus is limiting to freshwater marsh systems while salt marshes seem to be primarily nitrogen limited (Pigott, 1969; Gosselink, 1970).

In view of the insufficient understanding of the influence of salinity and soil nutrients on marsh production, this study was conceived. The objectives were to determine:

1) annual macrophytic angiosperm production in three Virginia salt marshes, each in a different salinity regime,

2) specific soil nutrient concentrations,

3) what correlations might exist between: a) salinity and productivity, and $\mathrm{b})$ soil nutrient concentrations and productivity, and

4) if plant nutrient concentrations were related to soil nutrient levels. 
REVIEW OF LITERATURE

Marsh Productivity Studies

\section{Salt Marshes}

The theory that tidal marshes play a large role in maintaining the fertility of the estuarine ecosystem (Odum, 1961) initiated numerous studies attempting to evaluate the potential productivity of these areas (Keefe, 1972). Resulting from these studies, one general trend seems to exist: a gradient of increasing salt marsh angiosperm production from North to South (Morgan, 1961, Kirby, 1971), which Morgan hypothesized to be due to the longer growing season in lower latitudes.

The work of Udell et al. (1969) and Stowe et al. (1971) are unique among the salt marsh primary productivity studies in that more than just the marsh grass component of the system was measured. The net primary productivity of Udell's Long Island marsh estuary was $3,658 \mathrm{~g} / \mathrm{m}^{2} \mathrm{yr}$ of which $68 \%$ was attributed to marsh grass, $21 \%$ to the macrophytic a1ga, Ulva lactuca, and $11 \%$ to phytoplankton.

Stowe et al. (1971) found marsh grass to account for $65 \%$ of the total primary production of a Louisiana marsh system, phytoplankton - 25\%, and epiphytic algae - 10\%. In both the above studies, the marsh grass component contributed the largest percentage of the total production. 
Although Stowe et al. (1971) and Udell et al . (1969) measured a considerable fraction of the marsh's total primary production, both neglected to evaluate microphytic benthic algal productivity. If we assume that in Stowe's study the benthic algal net production was comparable to that found by Pomeroy (1959) in a Georgia marsh $\left(180 \mathrm{gC} / \mathrm{m}^{2}\right)$, the total primary production of this Louisiana marsh is increased by $18 \%$, and the marsh grass component now accounts for $52 \%$ of the total primary productivity.

\section{Freshwater Marshes}

While the majority of salt marsh productivity studies have been performed in areas where the salinity is relatively high $(200 / 00$ to $36 \mathrm{o} / \mathrm{oo})$, few vegetative productivity studies in oligo-mesohaline marshes have been made and what data does exist has been obtained from peak standing crop measurements rather than complete growing season analysis (Pearsall and Gorham, 1956; Pearsall and Nerbold, 1957; Bray, Lawrence and Pearson, 1959; Jervis, 1964; Wass and Wright, 1969; Johnson, 1970; Van Dyke, 1972).

Jervis (1964), measuring primary productivity in a vegetationally diverse freshwater marsh in New Jersey, divided the vegetation in four communities, and found the cattail community to be slightly more productive, (1904 $\mathrm{gm} / \mathrm{m}^{2} \mathrm{yr}$ ) than the sedge-swale, open aquatic, and sedge-shrub communities, $1492 \mathrm{~g} / \mathrm{m}^{2} \mathrm{yr}, 1547 \mathrm{~g} / \mathrm{m}^{2} \mathrm{yr}$, and $1699 \mathrm{~g} / \mathrm{m}^{2} \mathrm{yr}$, respectively. Jervis concluded that the uniformly high rates of production among freshwater communities was due to the absence of critically limiting environmental factors. 


\section{Soil Parameters and Marsh Productivity}

The influence of abiotic factors, such as tidal elevation, submergence, nutrient concentration, chlorinity, aeration and soil solution salinity on plant distribution have been studied by a number of investigators (Harshberger, 1911; Johnson and York, 1915; Purer, 1942; Reed, 1947; Jackson, 1952; Hinde, 1954; Keith, 1958; Adams, 1963; Ranwe11, et a1., 1964; Ungar, 1965; Palmisano and Newson, 1967; Romig and Cotnoir, 1971; Gray and Bunce, 1972). These researchers conclude that the main factors controlling salt marsh plant distribution are salinity, tidal elevation, and submergence. In comparison, much less is known concerning the effects of these factors, and specifically soil parameters, on marsh productivity.

\section{Soil Salinity}

Laboratory experiments have shown that macrophytic angiosperm production decreases as salinity increases (Kaushik, 1963; Gosselink, 1970; Palmisano, 1970; Macke and Ungar, 1971; Mayer and Low, 1971; Ph1eger, 1971). Phleger (1971) found that the California cordgrass, Spartina foliosa, grew best when cultivated in a freshwater nutrient solution which is in agreement with what Adams (1963) found for $\underline{\text { S }}$ alterniflora and S. patens. Phleger concluded that salt marsh grasses must have originally been land or freshwater marsh plants which adapted to the coastal salt marsh environment. The presence of these plants in the salt marsh is, therefore, due to their inability to compete with either freshwater or terrestrial plants, and not to any physiological preference for a saltwater habitat. This might explain why marsh plants are considered facultative halophytes (Gosselink, 1970) whose growth in the laboratory is inversely related to salinity. 
Although this inverse relationship has not been validated in the field, energy flow studies in fresh (Bray, 1962) and salt marsh (Teal, 1962) communities suggest its existence. Bray determined that $30 \%$ of the gross primary productivity of a freshwater marsh was respired, while $77 \%$ was respired in Teal's high salinity salt marsh. This supports the hypothesis that the stressed environment of a high salinity salt marsh demands more energy for its physiological maintenance. Consequently, less energy per unit of biomass is available for the production of new biomass in salt marshes than in fresh marshes.

\section{Soij Nutrients}

Related edaphic factors such as soil nutrient composition and availability may, in addition to salinity, cause differential productivities. Boyd and Hess (1970) found that soil phosphorus concentrations accounted for $49 \%$ of the variation in productivity of a freshwater Typha marsh. The relatively low but significant product-moment correlation coefficient ( $r=0.71$ ) between soil phosphorus and standing crop may be due to a number of factors such as ecotypic variation between $\underline{T}$. latifolia populations, nutrient regime differences, or general environmental variations (Boyd and Hess, 1970).

Boyd and Hess (1970) suggested that phosphorus might be 1imiting to freshwater marshes. This does not seem to be true in saline environments. Berenyi (1966), using fertilizer experiments, found nitrogen to be the primary limiting nutrient to the growth of Spartina patens, although additions of phosphorus did have some growth stimulating effect. Gosselink (1970), studying the influence of nitrogen sources on $\underline{S}$. alterniflora production, found that the effect of $\mathrm{NO}_{3}^{-}-\mathrm{N}$ on production 
was slightly greater than $\mathrm{NH}_{4}{ }_{-} \mathrm{N}$; the differences, however, were not statistically significant. Valiela, et al., (1972) found that net primary production increased in wetland plots fertilized with sludge and urea; however, treatment with phosphate resulted in no response. In contrast, Pigott (1969) showed that Suaeda maritima and Salicornia europea growing in high marshes were nitrogen and phosphorus-limited, while plants growing in the low marshes were not limited by either nutrient. Stewart, et a1. (1972) using nitrate reductase activity as an index of soil nitrate availability, found high activity in Suaeda maritima in the low marsh which implied high nitrate availability and confirmed Pigott's suggestion that nitrogen is not limiting in this part of the marsh.

Jeffrey (in Pigott, 1969) determined that although total nitrogen and phosphorus concentrations increased landward on the marsh, the plant-available forms such as nitrate and ammonia had similar concentrations throughout the marsh. Jeffrey, therefore, concluded that the significant differences in production between marsh zones may be due to the extent to which the sediment is utilized by the root system of the plants present.

Marsh Plant Nutrients and Environmental Concentrations

Investigations in the use of plant nutrient concentrations as an estimate of environmental nutrient availability have met with conflicting results (Gerloff and Skoog, 1954; Gerloff and Krombhalz 1966; Boyd, 1970a; Boyd and Hess, 1970; Boyd, 1971; Gossett and Norris, 1971; Bayly and O'Neil1, 1972a, 1972b; Dietz, 1972). 
Significant Correlations

Gerloff and Skoog (1954) showed for the blue-green alga, Microcystis aeruginosa, that internal nitrogen and phosphorus concentrations increased as the external supply increased. Working with aquatic angiosperms, Gerloff and Krombholz (1966) found that the nitrogen and phosphorus content of these plants correlated well with the fertility of their habitat. Gossett and Norris (1971) showed a positive relationship between the nitrogen and phosphorus content of the water hyacinth, Eichornia crassipes, and the nitrogen and phosphorus content of the environment. In contrast to the positive relationships between environmental and tissue nutrient concentrations, Bayly and o'Neil1 (1972) found a negative interdependence between phosphorus in the shoot tissue of Phragmites communis and soil nutrient levels.

\section{Non-Significant Correlations}

In other studies, plant and environmental nutrient levels were not found to be significantly correlated. Boyd and Vickers (1971), found no correlation between macronutrients in water hyacinth tissue and its environment. Dietz (1972), in agreement with Boyd and Vickers (1971), made the general statement that macronutrient concentrations of aquatic plants are largely independent of the local medium. Boyd and Hess (1970) found that soil nutrient concentrations accounted for only $32 \%$ of the variability in tissue concentrations of Typha latifolia.

The "ecomix theory" (Odum, 1960) states that the accumulation of nutrients by biomass is in the same ratio that the nutrients occur in the environment. Boyd (1970a), however, found no correlation between the ratio of plant nutrients and water nutrients and concluded that Odum's "ecomix theory" may be invalid for vascular aquatic plants. 
The nutrient content of aquatic plants show large variations among the same species in the same and in different environments and among different species in the same environment (Gerloff and Krombholz, 1966; Boyd, 1969; Boyd, 1970b). These differences may be related to environmental nutrient levels, differential absorption by various species, and/or differential absorption by individuals of the same species in a different environment: Therefore, care must be taken in extrapolating plant nutrient concentrations of a species population in one marsh to other species in the same marsh or the same species in different marshes. 
MATERIALS AND METHODS

Determination of Primary Production

Three regularly flooded marshes, Ware Creek, Carter Creek, and Wachapreague, (Fig. 1), were chosen for study based on their salinity range and ease of accessibility.

Wachapreague Marsh is located on the Eastern Shore of Virginia and is approximately eight acres in size. It is an euhaline marsh, having a mean salinity of $30 \mathrm{o} / 00$. This marsh consists of a monospecific stand of Spartina alterniflora, although some Salicornia virginica does occur.

Carter and Ware Creek Marshes are part of the York River Estuarine System. Carter Creek Marsh, 18 acres in extent and having a mean salinity of approximately $10 \mathrm{o} / \mathrm{oo}$, is also dominated by $\underline{\text { s. alterniflora, }}$ and, in addition, has extensive stands of a mixture of Distichlis spicata and $\underline{S}$. patens. The Ware Creek Marsh encompasses 38 acres and is an oligohaline marsh, having a mean salinity of 4 o/oo. S. cynosuroides is the dominant of this marsh.

Net primary productivity was determined by the frequent harvest method which entails algebraically summing the changes in standing crop of marsh grasses periodically throughout the growing season. If only the change in living standing crop is determined, productivity is 


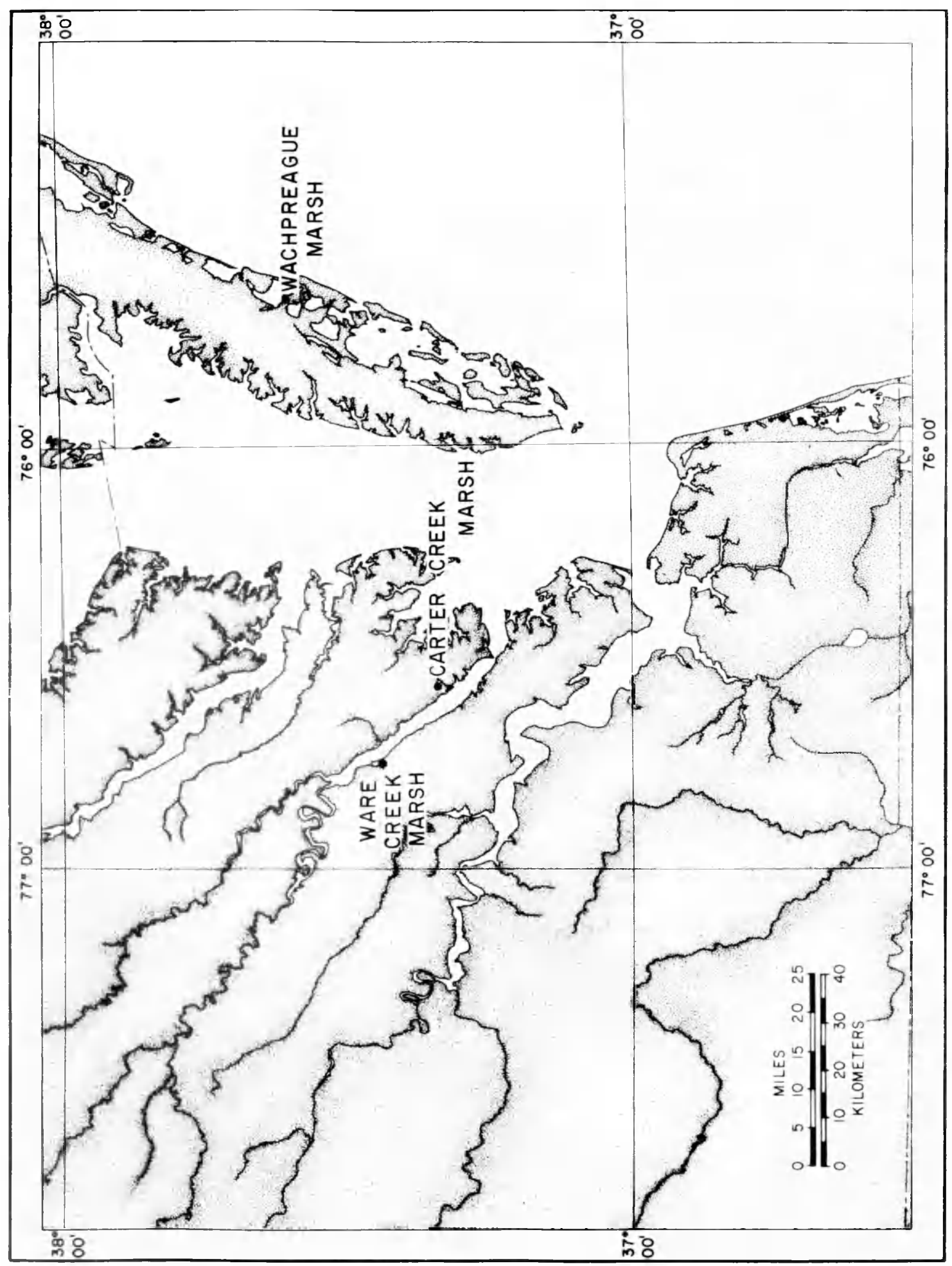


Figure 1. Location of the Ware Creek, Carter Creek and Wachapreague Marshes. 
underestimated due to the death of some plants and leaf fall from others. Smalley's (1958) modification of the frequent harvest method (used in this study) overcomes this problem by considering not only changes in living, but also changes in dead standing crop. His method is as follows:

1) If there is an increase in both living and dead standing crop, net production is the sum of the increases for that sampling period.

2) If both living and dead standing crop decrease, then production is zero.

3) If the living standing crop increases and the dead standing crop decreases, production is equal to the increase in the living.

4) If there is a decrease in the living and an increase in the dead, production is zero unless the dead increase is greater than the living decrease in which case net production equals the algebraic sum of the two.

Vegetational and marsh soil parameters were collected at 25 randomly selected sites in each marsh six and four times, respectively, throughout the growing season. Randomness was achieved by dividing each marsh into plots twenty-five meters square and selecting twentyfive of these via a random numbers table. The individual sampling sites were chosen by using a random coordinate number system from a random numbers table (Reimold, personal communication). 
Marsh grass samples were collected within $0.25 \mathrm{~m}^{2}$ circular quadrats. Living and dead plants, clipped at ground level, plus all litter were collected from each plot and returned to the laboratory for analysis. A circular quadrat which reduces the perimeter to area ratio was chosen to reduce the variability of standing crop data due to the edge effect (Van Dyne et al., 1963).

In the laboratory, each sample was separated into living and dead categories, washed to remove marsh mud, and the number of living stems of each species determined. If a plant had lost more than $50 \%$ of its chlorophy11, as estimated visua11y, it was added to the dead category; otherwise, it was considered living. Living and dead plants were placed in paper bags and oven-dried to a constant weight at $110^{\circ} \mathrm{C}$ for approximately 48 hours. Samples were weighed to the rearest tenth of a gram.

\section{Soil Analysis}

Core samples of marsh soils were taken from the center of each quadrat after the vegetation therein was clipped. The coring device was a cylindrical metal tube attached to a shovel handle. Core samples approximately $20 \mathrm{~cm}$ deep and $8 \mathrm{~cm}$ in diameter were returned to the laboratory and frozen.

Soil samples, after being thawed, were prepared for analysis by washing the soil from the root material through a 500 u sieve with deionized water. 
Magnesium, potassium, and calcium were extracted from the marsh soil with concentrated nitric acid, (Huggett and Bender, 1971) and the extractant analyzed for these ions on a Varian Techtron Model AA-5 atomic absorption spectrophotometer. Total nitrogen was determined by a modified Kjeldahl method (American Instrument Company, 1959). Total phosphorus was extracted by digesting the soil in a 1:1 nitric-sulfuric acid mixture, and the concentration was determined by the phosphomolybdate colorimetric test (E.P.A., 1971).

Soil $\mathrm{pH}$ was determined with a Fisher automatic titrimeter $\mathrm{pH}$ meter on a 1:10 soil-solution ratio which was allowed to stand for six hours before testing.

Soil solution water samples were obtained by placing a salinity bottle in the hole made by the coring device and collecting the interstitial water. Concentrations were determined on a Beckman model RS-7B portable induction salinometer. It was sometimes necessary to work on flood tides which completely covered the marsh surface and made it impossible to collect interstitial salinities. In this case, surface water samples were taken.

Plant Tissue Analysis

Spartina alterniflora leaves and stems, collected from Wachapreague Marsh throughout the growing season and from Carter and Ware Creek Marshes during the period of peak standing crop, were dried, ground in a Waring blender and stored in sealed bottles for chemical analysis of total kjeldahl nitrogen and total phosphorus, using the same methods as for the marsh soils. 


\section{Data Analysis}

\section{Sorenson's Index and Cluster Analysis}

Sorenson's index (Kontkanen, 1957), which provides an expression of the percent co-occurrence of two species, was used to calculate association indices for plant species in each marsh. Sorenson's index is calculated by the formula:

$$
S=\frac{2 c}{a+b} \times 100
$$

where:

$$
\begin{aligned}
S= & \text { Sorenson's index } \\
C= & \text { the number of co-occurrences of } \\
& \text { species } A \text { and } B \\
a= & \text { the number of occurrences of } \\
& \text { species } A \\
b= & \text { the number of occurrences of } \\
& \text { species } B .
\end{aligned}
$$

Cluster analysis was performed using group average sorting (Sokal and Sneath, 1963; Lance and Williams, 1967) and dendrograms constructed.

\section{Species Dominance Values}

A species dominance value (SDV) was used to further characterize the species composition and structure of each marsh. The SDV was calculated by the formula:

$$
\mathrm{SDV}=\mathrm{RF}+\mathrm{RD}+\mathrm{RSC}
$$


where:

$\mathrm{SDV}=$ Species Dominance Value
$\mathrm{RF}=$ Relative Frequency, which is equal to
the number of times the species occurred
per the number of times all species occurred.
$\mathrm{RD}=$ Relative Density, which is equal to the mean
density for the species per the sum of the
mean densities of all species.
Relative Standing crop, which is equal to the
mean standing crop of the species per the
sum of the mean standing crops of all species.

Since $R F$, RD, and RSC are percentage values, the largest possible SDV is 300 which only occurs in monospecific stands. As the number of species in a marsh increases, the maximum values for SDV decreases.

Relative Dominance Values

A Relative Dominance Value (RDV) was derived to compare the dominance of a species in one marsh relative to other marshes. The RDV is equal to the dominance value of a species in a particular marsh per the sum of the dominance values of the same species in each marsh.

Analysis of Variance, Student-Newman-Keuls' Multiple Range Test, and Correlation Analysis

The one-way classification of analysis of variance was used for tests of significance among means. The null hypothesis that the treatments were equal was rejected if the probability of committing 
an alpha error was greater than 0.05 . One asterisk indicates the $5 \%$ significance leve1, and two, the $1 \%$ significance level. Data in ratio form were normalized by using the angular sine transformation (Steele and Torrie, 1960). Student-Newman-Keuls' multiple range test (Steele and Torrie, 1960) was used to decide which treatment means were significantly different. In the tables of the Appendix, any two means not underscored by the same line were significantly different, while any two means underscored by the same line were not significantly different.

Correlation analysis was used to measure the co-relationship of two variables. The significance level was held at $\mathrm{P} \leq 0.05$ (Steele and Torrie, 1960).

\section{Multiple Regression}

A stepwise multiple regression (Dixon, 1968) which regressed standing crop on soil total kjeldahl nitrogen (TKN), total phosphorus (TP), magnesium $(\mathrm{Mg})$, potassium $(\mathrm{K})$, calcium $(\mathrm{Ca})$, salinity, and $\mathrm{pH}$ was

used to detect which environmental parameters had the greatest effect on marsh grass standing crop. The significance level for variable inclusion was $1 \%$. 


\section{RESULTS}

\section{Community Composition}

\section{Species Association}

A total of 15 species of plants were found in oligohaline Vare Creek Marsh, and consequently yielded a greater species richness value than was found for mesohaline Carter Creek Marsh (12 species present) or euhaline Wachapreague Marsh (2 species present), (Table I).

A dendrogram of species in Ware Creek Marsh (Fig. 2) showed two associations, $A$ and $B$, (Table 2) the former was further divided into sub-associations $A_{1}$ and $A_{2}$.

A dendrogram of species in Carter Creek Marsh (Fig. 3) also showed two primary associations, $C$ and $D$ (Table 2).

Since only two species were present in Wachapreague Marsh, only one association existed: Spartina alterniflora and Salicornia virginica. Sorenson's index for this species association was 0.09 or $9 \%$ association.

Dominance

\section{Species Dominance Values (SDV)}

Spartina cynosuroides, having a SDV of 81 , was the dominant plant species in Ware Creek Marsh (Fig. 4). $\underline{\text { S. alterniflora and Juncus }}$ spp., having SDV's of 50 and 52 , respectively, were strong subdominants. The SDV's of freshwater-brackish species such as Typha angustifolia, Polygonum punctatum, Leersia oryzoides, Hibiscus moscheutos, and Peltandra virginica were relatively small (Fig. 4). 

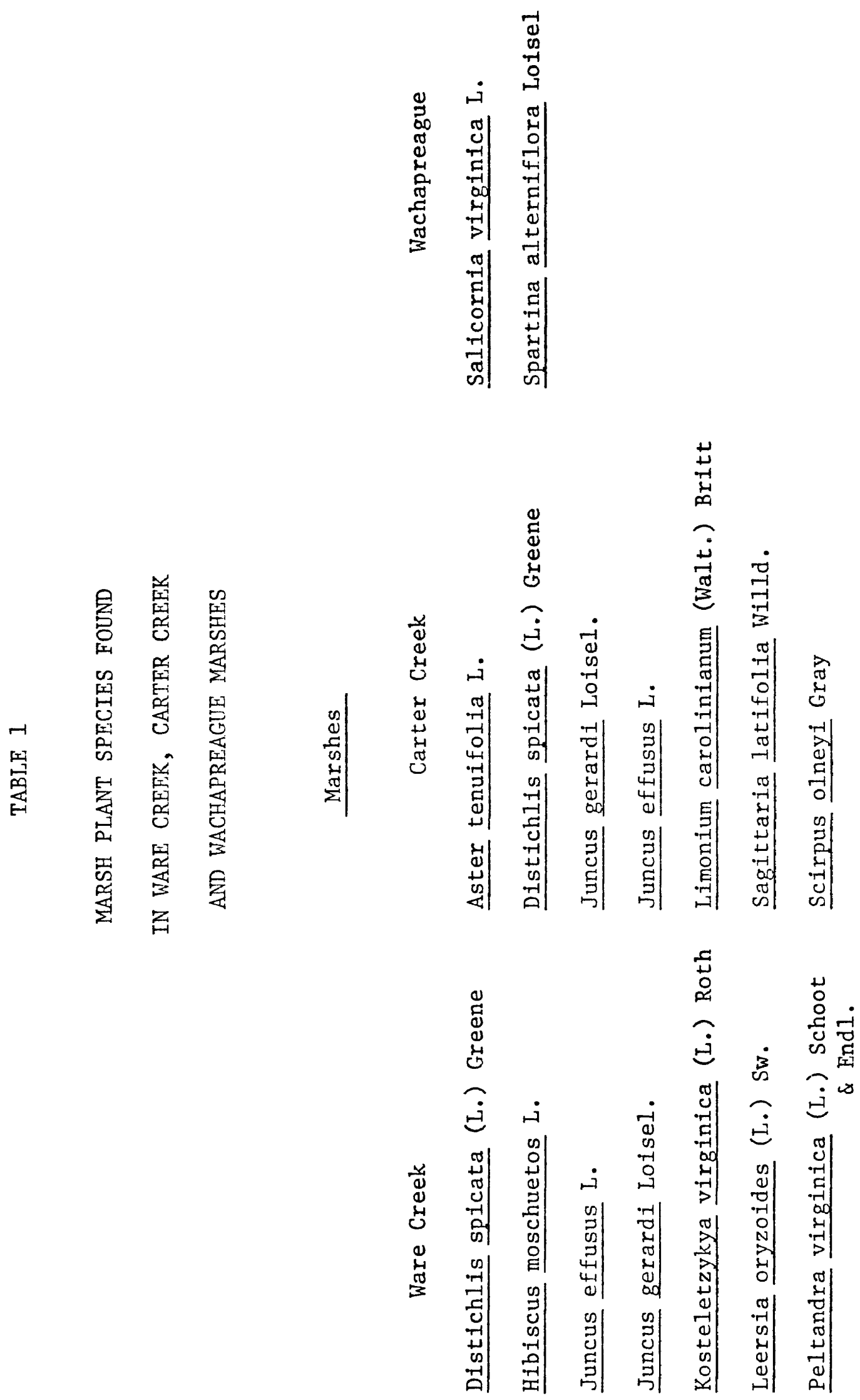


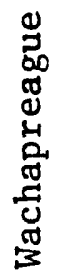

䓀
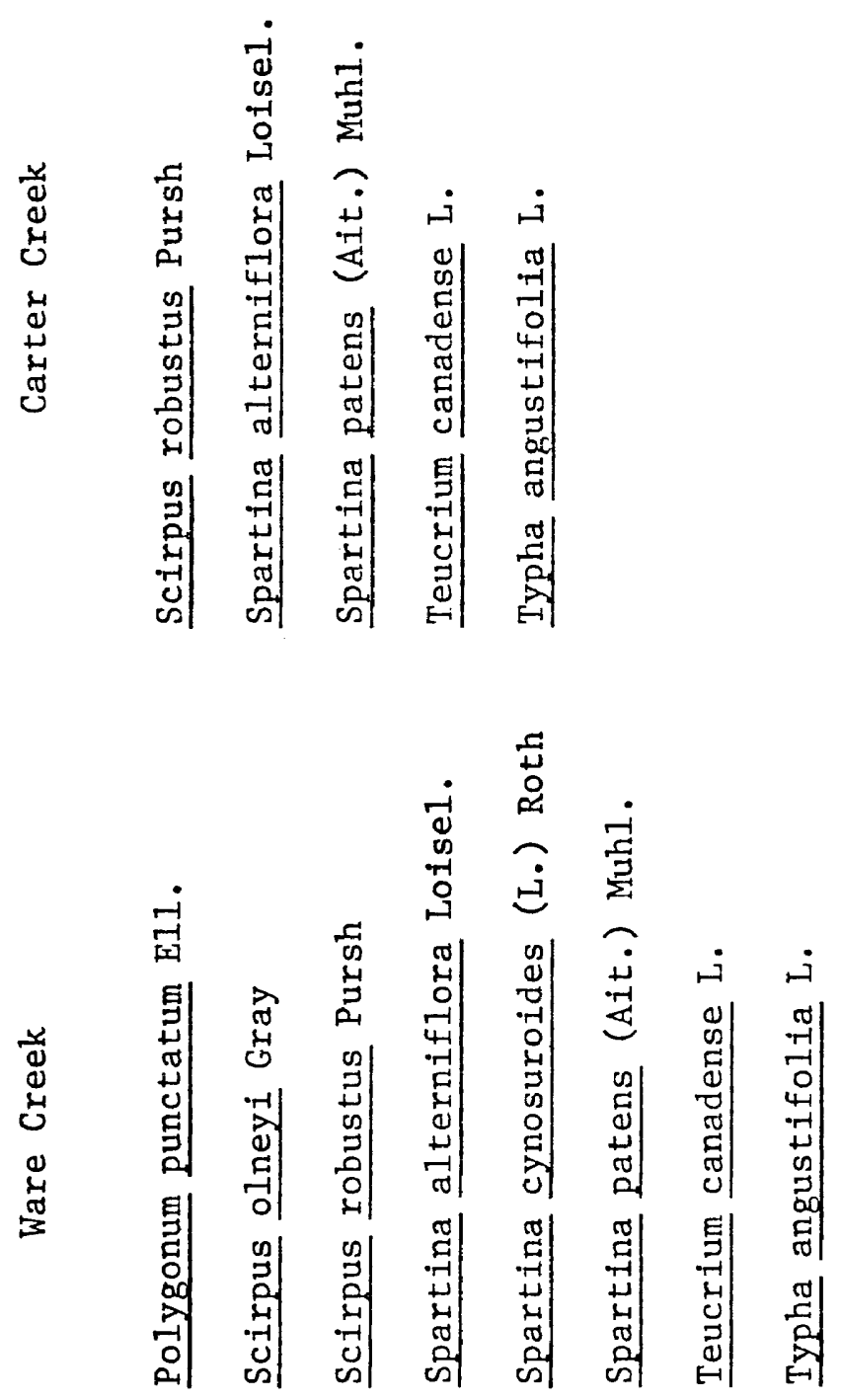
Figure 2. Dendrogram of species associations in Ware Creek Marsh. 


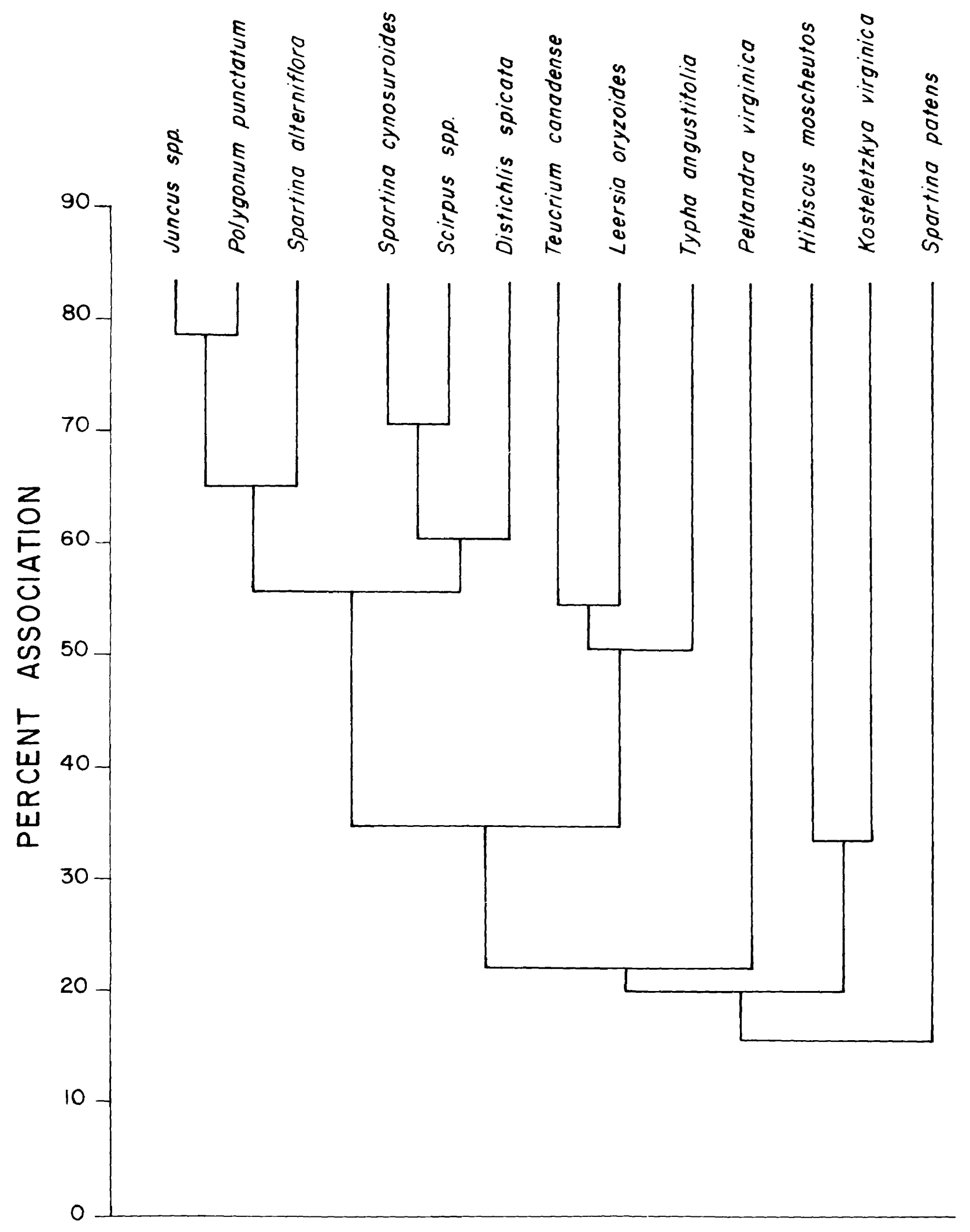




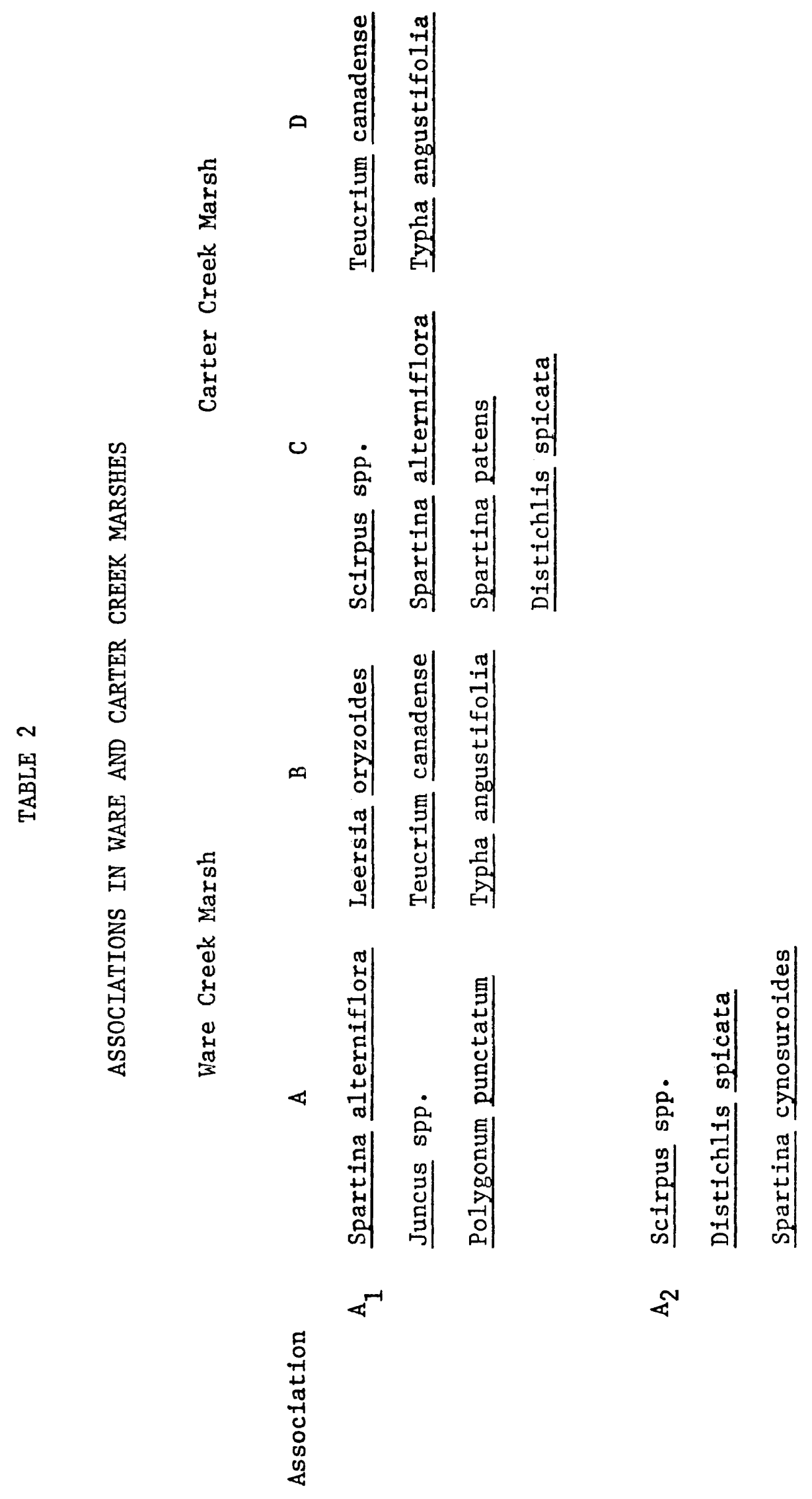


Figure 3. Dendrogram of species associations in Carter Creek Marsh. 


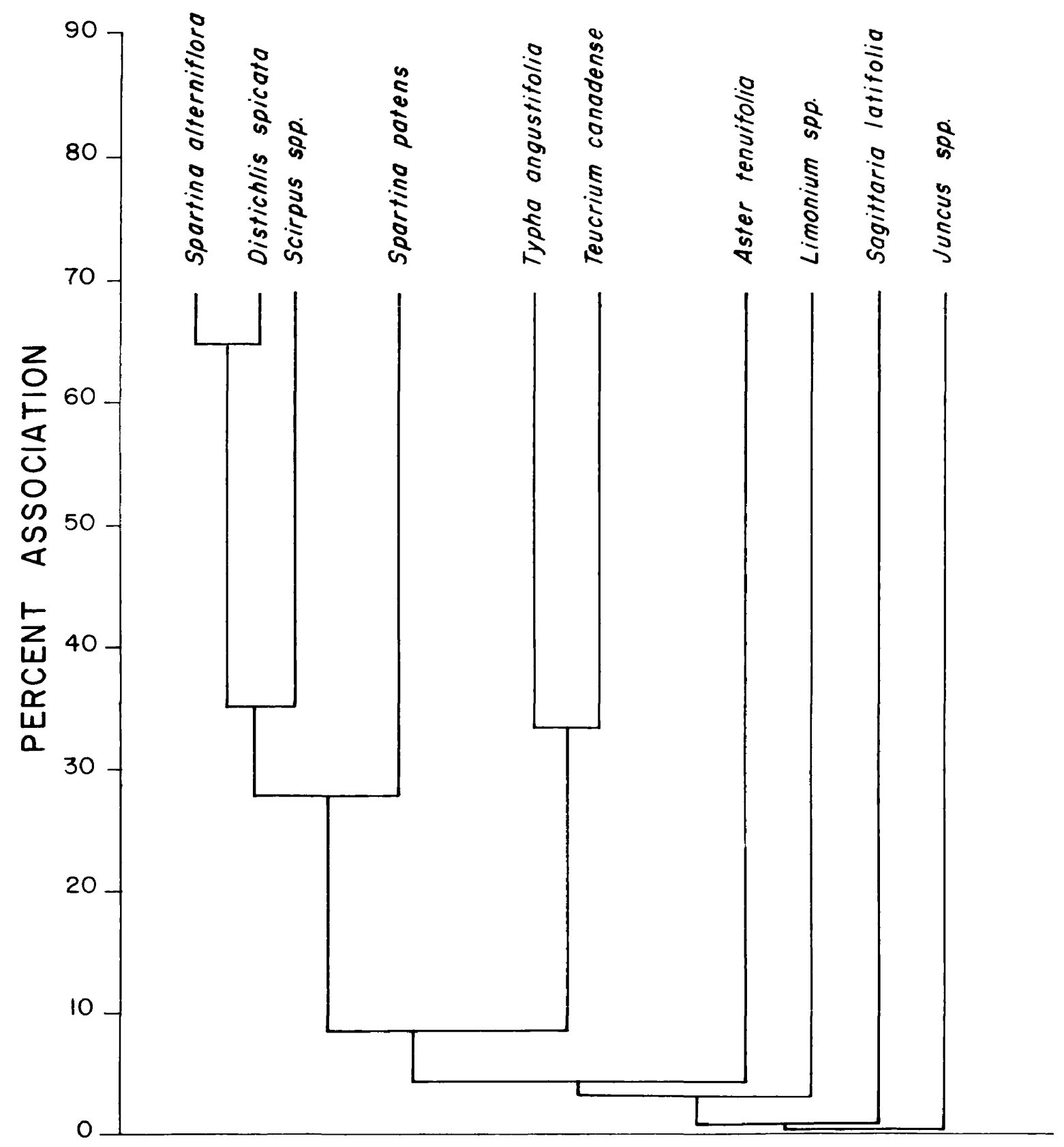


Figure 4. Species dominance values for various marsh plant species in Ware Creek Marsh. 


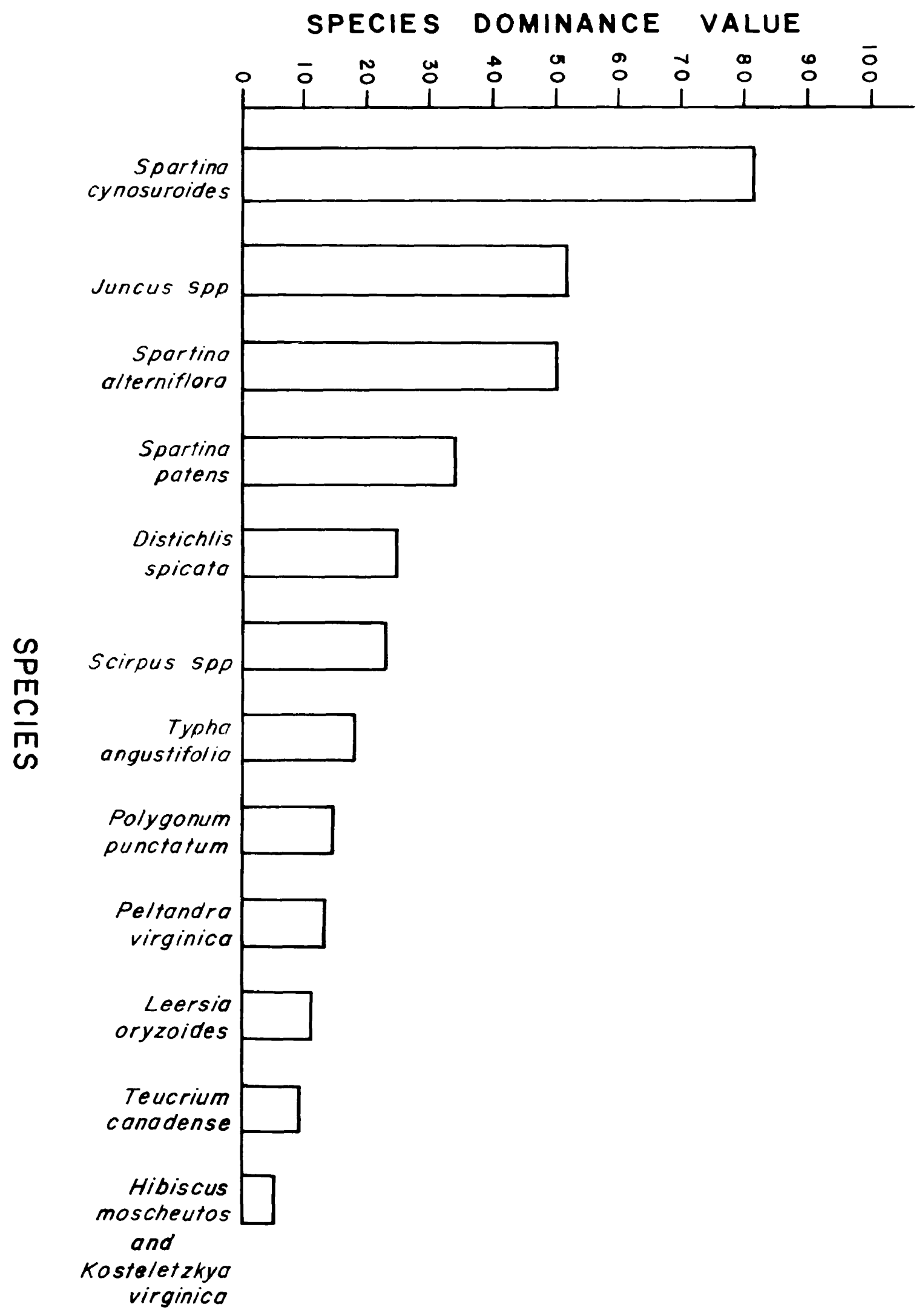




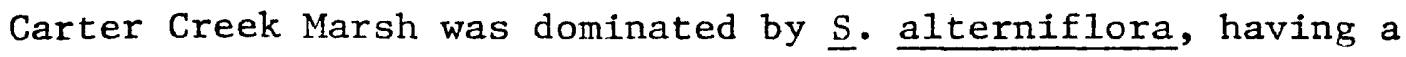
SDV of 115, while the major subdominants, $\underline{\text { s. patens }}$ and Distich1is spicata, had SDV's of 77 and 68 respectively (Fig. 5).

Wachapreague Marsh was dominated by $\underline{s}$. alterniflora, having a SDV of 280, while the only other species present, Salicornia virginica, had a SDV of 20 (Fig. 6).

\section{Relative Dominance Values (RDV)}

Table 3 compares the RDV's of various plant species in the three marshes studied. $\mathrm{RDV}^{\prime}$ s for the more saline tolerant species, such as Spartina alterniflora, S. patens, Distichlis spicata, and Salicornia virginica, were larger in the higher salinity marshes.

\section{Angiosperm Primary Production}

Net Annual Primery Production

The net annual primary production of Ware Creek, Carter Creek, and Wachapreague Marshes were $563 \mathrm{~g} / \mathrm{m}^{2}, 572 \mathrm{~g} / \mathrm{m}^{2}$, and $362 \mathrm{~g} / \mathrm{m}^{2}$, respectively (Tables 4, 5, and 6). Euhaline Wachapreague Marsh had the lowest production, while oligohaline Ware and mesohaline Carter Creek Marshes had higher productions (Table 7).

\section{$\underline{\text { Seasonal Trends }}$}

\section{Living Standing Crop}

The seasonal changes in living standing crop in Ware Creek, Carter Creek, and Wachapreague Marshes were relatively similar (Fig. 7), although Ware Creek Marsh reached its peak standing crop approximately $2-21 / 2$ months before the others. Ware Creek Marsh also had a much faster initial growth rate, $5.2 \mathrm{~g} / \mathrm{m}^{2} \mathrm{day}$, than either Carter Creek or Wachapreague Marshes, $2.4 \mathrm{~g} / \mathrm{m}^{2}$ day and $2.1 \mathrm{~g} / \mathrm{m}^{2}$ day, respectively. 
Figure 5. Species dominance values for various marsh plant species in Carter Creek Marsh. 


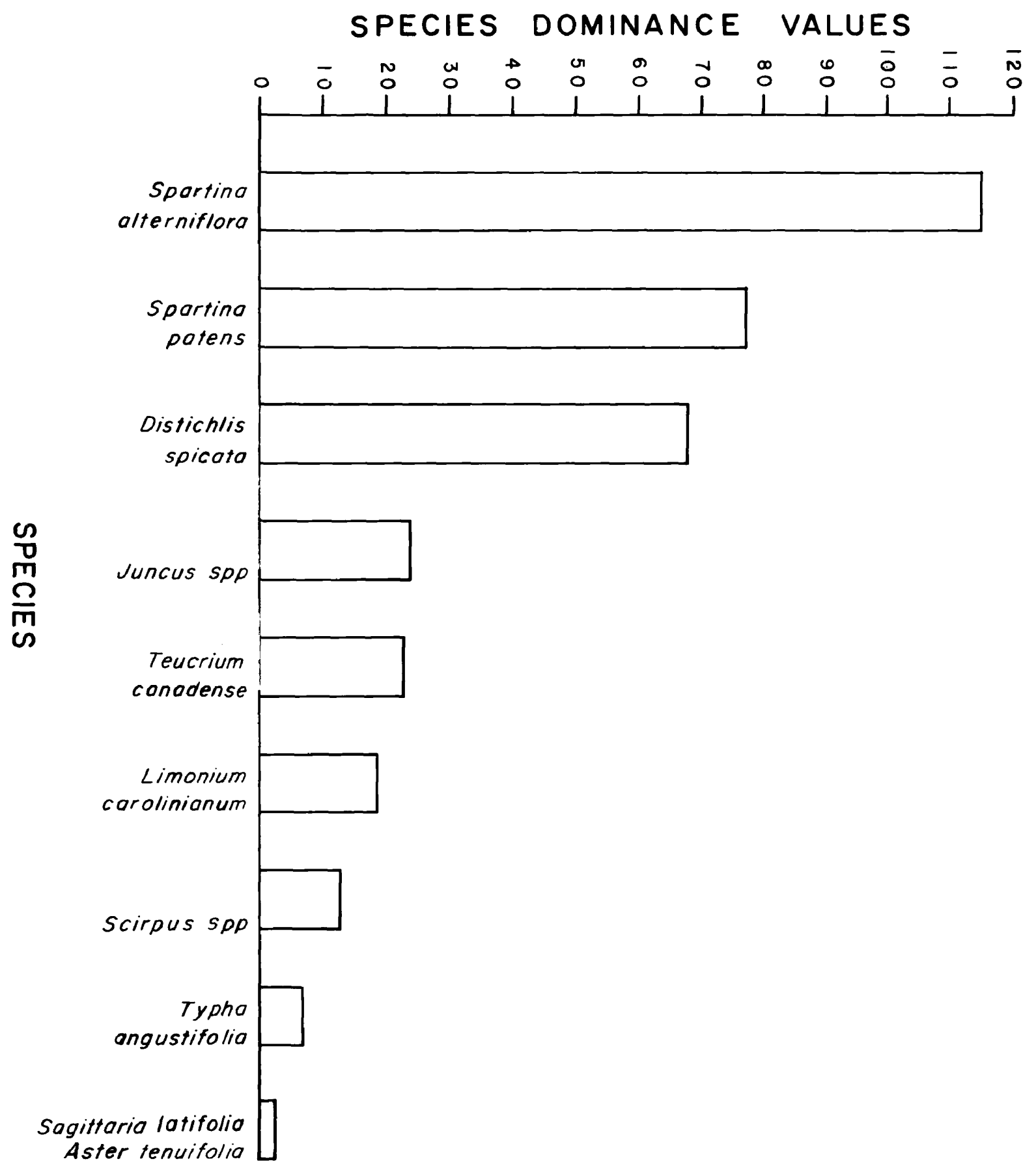


Figure 6. Species dominance values for species in Wachapreague Marsh. 


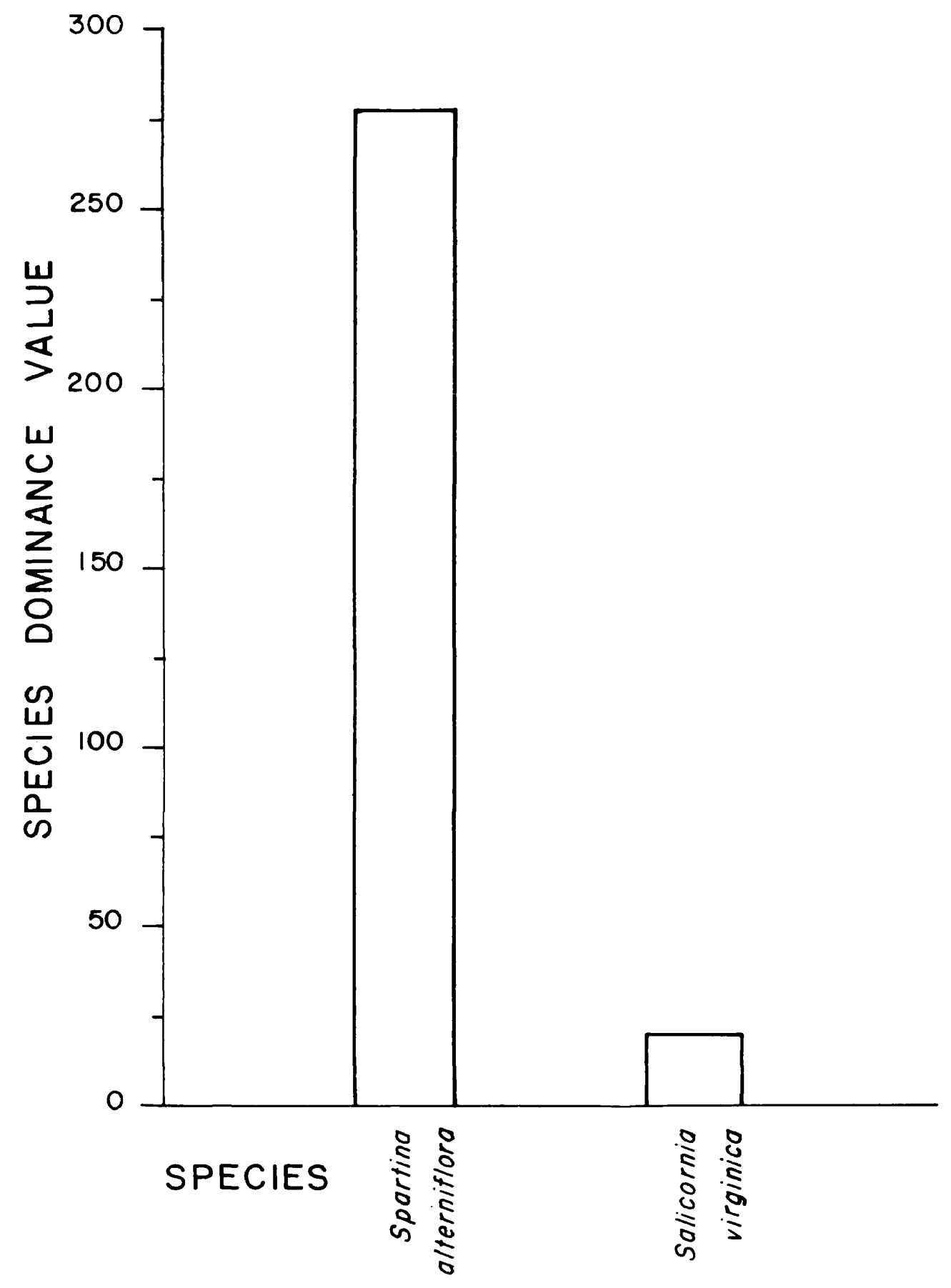


TABLE 3

RELATIVE DOMINANCE VALUES OF

VARIOUS MARSH PJANT SPECIES IN

WARE CREEK, CARTFR CREEK, AND

WACHAPREAGUE MARSHES

MARSHES

Species

Ware Creek Carter Creek Wachapreague

Spartina alterniflora

11

26

63

Spartina patens

30

70

0

Spartina cynosuroides

100

0

0

Distichlis

27

73

0

Scirpus spp.

64

36

0

Juncus spp.

68

32

0

Typha angustifolia

73

27

0

Teucrium canadense

29

71

0

Peltandra virginica

100

0

0

Leersia oryzoides

100

0

0

Polygonum punctatum

100

0

0

Hisbuscus moscheutos

100

0

0

Kosteletzkya virginica

100

0

0

Salicornia virginica

0

0

100 
TABLE 4

\section{CALCULATION OF NET PRIMARY PRODUCTION \\ OF WARE CREEK MARSHES WITH THE USE \\ OF. SMALLEY'S (1958) METHOD \\ (g dry weight $/ \mathrm{m}^{2}$ )}

$$
\begin{aligned}
& \text { Standing Crop Change In } \\
& \pm \mathrm{SE}
\end{aligned}
$$

Sampling Date

Living

Dead

Living

Net

19 March 1972

$$
5 \pm 1 \quad 641 \pm 60
$$

$\begin{array}{lll}138 & -181 & 138\end{array}$

17 May 1972

$$
143 \pm 12 \quad 460 \pm 60
$$

$403-18 \quad 403$

7 July 1971

$$
546 \pm 46 \quad 442 \pm 51
$$

$\begin{array}{lll}-47 & -14 & 0\end{array}$

12 August $1971 \quad 499 \pm 58 \quad 428 \pm 56$

$-7 \quad-77$

24 September $1971 \quad 492 \pm 40 \quad 351 \pm 47$

$\begin{array}{lll}-307 & 329 & 22\end{array}$

4 November $1971 \quad 185 \pm 16 \quad 680 \pm 86$

Annual Production $=563 \mathrm{~g} / \mathrm{m}^{2} \mathrm{yr}$. 
TABLE 5

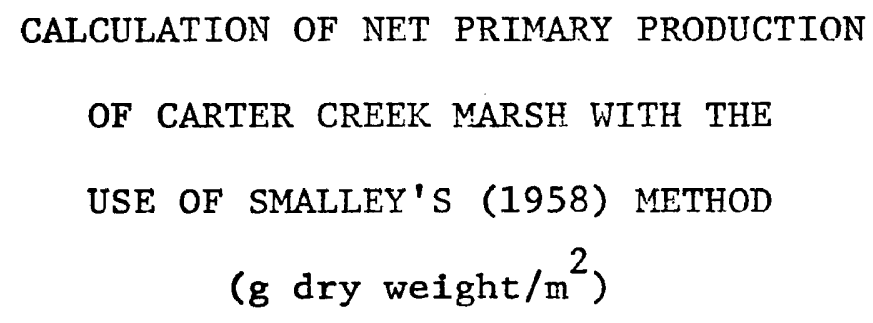

Standing Crop

Change In

$$
\pm \mathrm{SE}
$$

Sampling Date

$\begin{array}{ll}\text { Living } & \text { Dead } \\ 2 \pm 1 & 500 \pm 32\end{array}$

Living Dead $\begin{gathered}\text { Net } \\ \text { Production }\end{gathered}$

21 March 1972

$94-136 \quad 94$

12 May 1972

$$
96 \pm 12 \quad 364 \pm 32
$$

$144 \quad 60 \quad 204$

29 June 1971

$$
240 \pm 18 \quad 424 \pm 36
$$

$\begin{array}{lll}156 & -138 & 156\end{array}$

4 August 1971

$$
396 \pm 28 \quad 286 \pm 21
$$

$\begin{array}{lll}71 & 47 & 118\end{array}$

14 September $1971 \quad 467 \pm 43 \quad 333 \pm 34$

$-152-6 \quad 0$

27 October 1971
$315 \pm 35 \quad 327 \pm 39$

Annual Production $=572 \mathrm{~g} / \mathrm{m}^{2} \mathrm{yr}$ 
TABLE 6

\begin{abstract}
CALCULATION OF NET PRIMARY PRODUCTION
OF WACHAPREAGUE MARSH WITH THE USE

OF SMALLEY'S (1958) METHOD

(g dry weight $/ \mathrm{m}^{2}$ )
\end{abstract}

Standing Crop Change In
$\pm \mathrm{SE}$

Sampling Date

$\begin{array}{cc}\text { Living } & \text { Dead } \\ 13 \pm 1 & 196 \pm 29\end{array}$

Net

Living Dead Production

23 March 1972

89

$-106$

89

31 May 1972

$102 \pm 6 \quad 90 \pm 8$

150

11

161

13 July 1971

$252 \pm 22 \quad 101 \pm 19$

111

$-7$

112

25 August 1971

$363 \pm 50 \quad 94 \pm 14$

$$
-93
$$

$-15$

0

12 October 1971

$$
270 \pm 40 \quad 79 \pm 12
$$

$$
-153
$$

99

0

18 November $1971 \quad 117 \pm 28 \quad 178 \pm 11$

$$
\text { Annual Productions }=362 \overline{\mathrm{g} / \mathrm{m}^{2} \mathrm{yr}}
$$


TABLE 7

SALINITY, DOMINANT SPECIES, AND

PRODUCTIVITY OF WARE CREEK, CARTER

CREEK, AND WACHAPREAGUE MARSHES

\begin{tabular}{|c|c|c|c|c|}
\hline Marsh & $\begin{array}{l}\text { Productivity } \\
\quad\left(\mathrm{g} / \mathrm{m}^{2} \mathrm{yr}\right)\end{array}$ & $\begin{array}{l}\text { Salinity } \\
\text { Range } \\
(0 / 00)\end{array}$ & $\begin{array}{l}\text { Mean } \\
\text { Salinity } \\
(0 / 00)\end{array}$ & $\begin{array}{l}\text { Dominant } \\
\text { Species }\end{array}$ \\
\hline
\end{tabular}

Ware Creek

Carter Creek

Wachapreague
563

$0.6-11.0$

572

$0.6-19.0$

10

362
$28.0-33.0$

30
4

Spartina cynosuroides

S. alterniflora Juncus spp.

S. alterniflora Distichlis spicataS. patens mixture

S. alterniflora 
Figure 7. Seasonal changes in living standing crop in Ware Creek, Carter Creek, and Wachapreague Marshes.

Vertical lines represent one standard error (SE) 


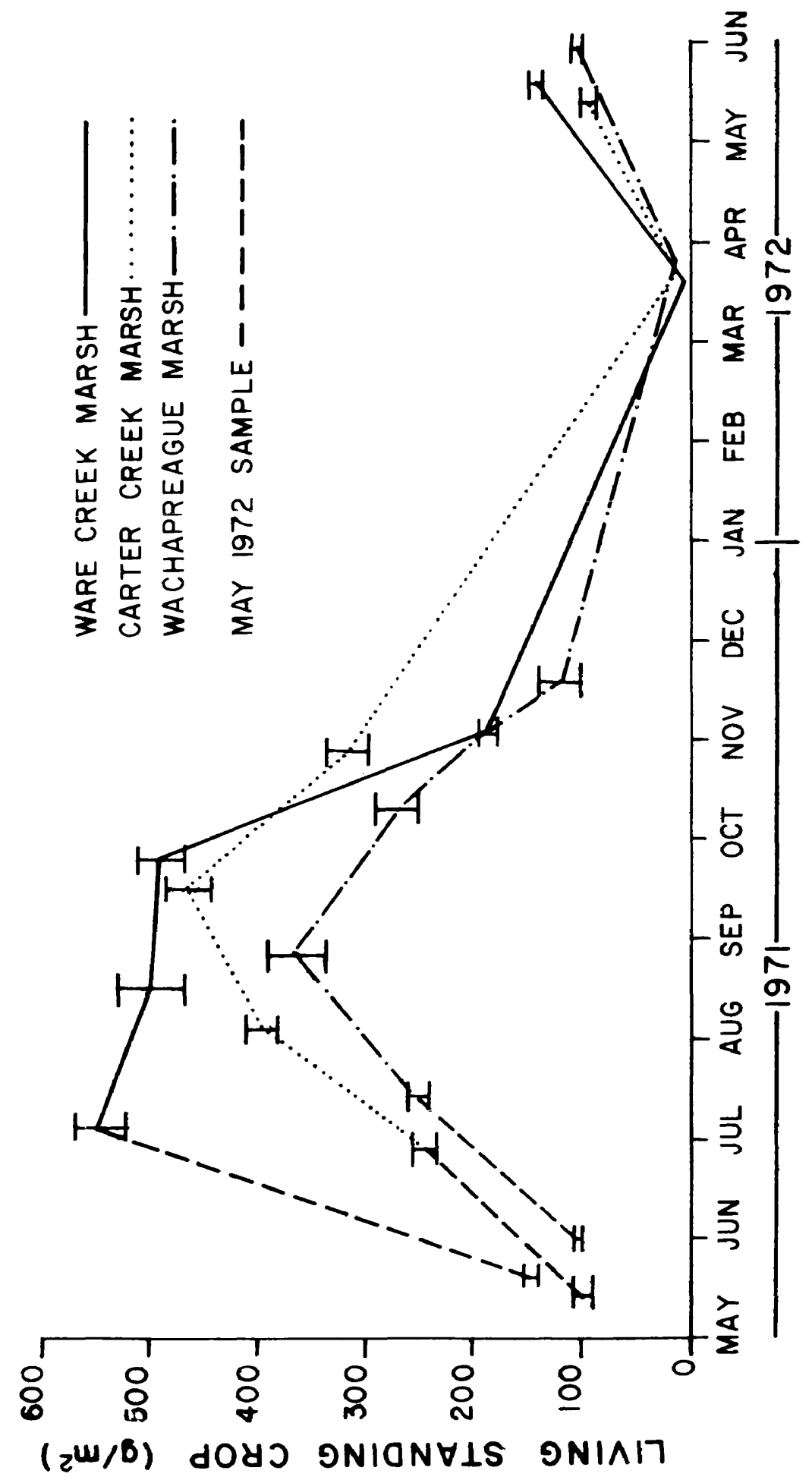




\section{Dead versus Living Standing Crop}

The seasonal changes in dead standing crop, which were inversely proportional to living standing crop, were also similar in the three marshes (Fig. 8). The dead standing crop was lowest in the late summer, increased in the late fall, leveled off to a winter maximum, and decreased gradually in the spring to its summer minimum. Although this trend was similar in each marsh, the mean annual amount of dead standing crop in Ware, Carter, and Wachapreague Marshes $\left(501 \mathrm{~g} / \mathrm{m}^{2}, 371 \mathrm{~g} / \mathrm{m}^{2}\right.$, and $122 \mathrm{~g} / \mathrm{m}^{2}$, respectively) were significantly different (Appendix, Table A1).

\section{Living to Dead Standing Crop Ratio}

The ratio of living to dead standing crop (L/D) was very similar in Ware and Carter Creek Marshes with a maximum of 1.4 in both (Fig. 9), but significantly different (Appendix, Table A2) from that (3.9) found in Wachapreague Marsh.

\section{Marsh Soil Parameters}

\section{Mean Concentrations}

Carter Creek, Ware Creek, and Wachapreague Marshes were distinct with respect to their nutrient regimes (Table 8). Total kjeldahl nitrogen (TKN) and total phosphorus (TP) concentrations in Wachapreague Marsh were significantly less (Appendix, Tables A3 and A4, respectively) than that found in Carter and Ware Creek Marshes. Although TKN concentratrations In Carter and Ware Creek Marshes were also significantly different, TP concentrations were not (Appendix, Tables A3 and A4, respectively). Magnesium concentrations were significantly higher (Appendix, Table A5) in Carter Creek and Wachapreague Marshes compared 
Figure 8. Comparison of living and dead standing crop in Ware Creek, Carter Creek, and Wachapreague Marshes. 


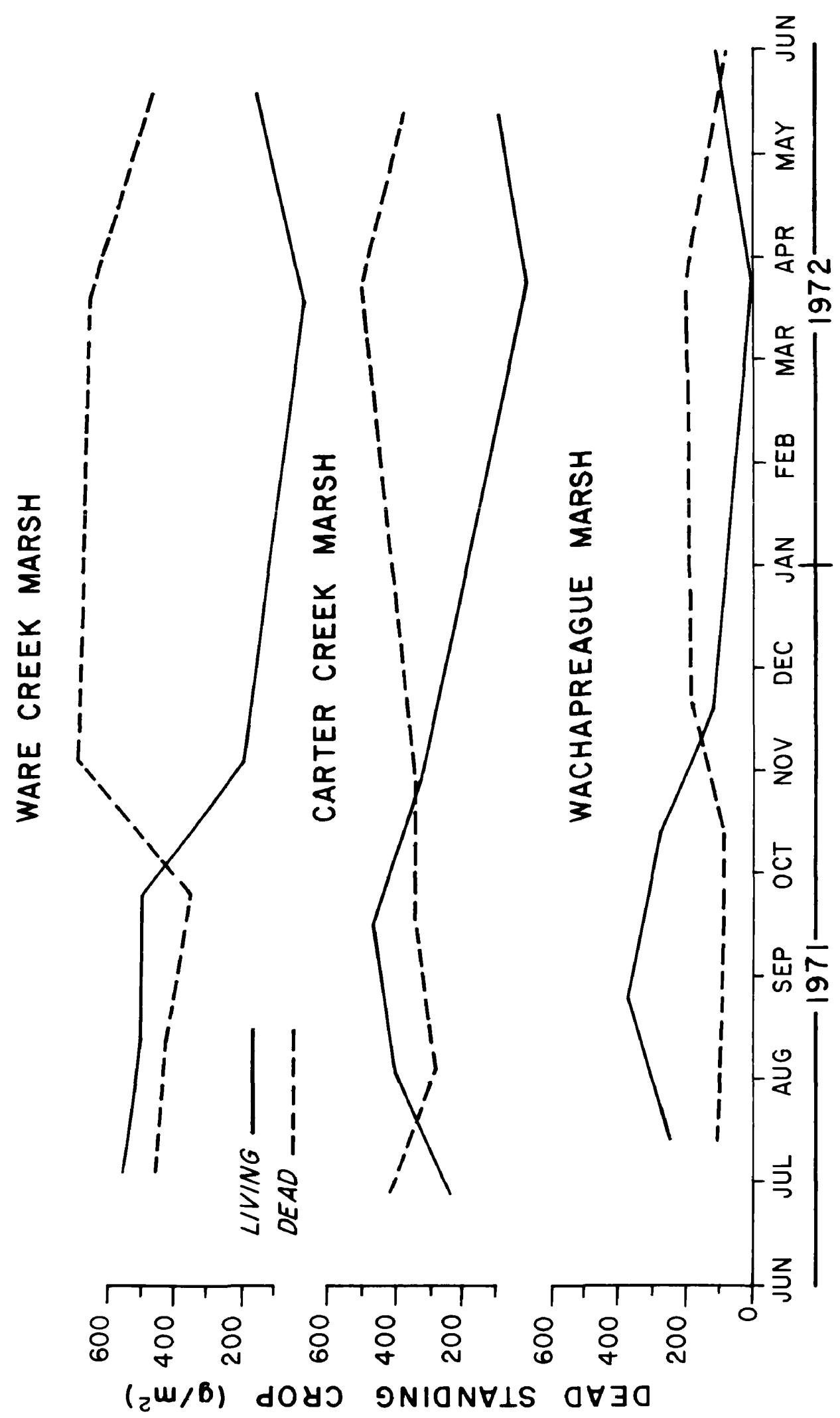


Figure 9. Seasonal changes in the living to dead standing crop ratio in Wachapreague, Carter Creek, and Ware Creek Marshes. 


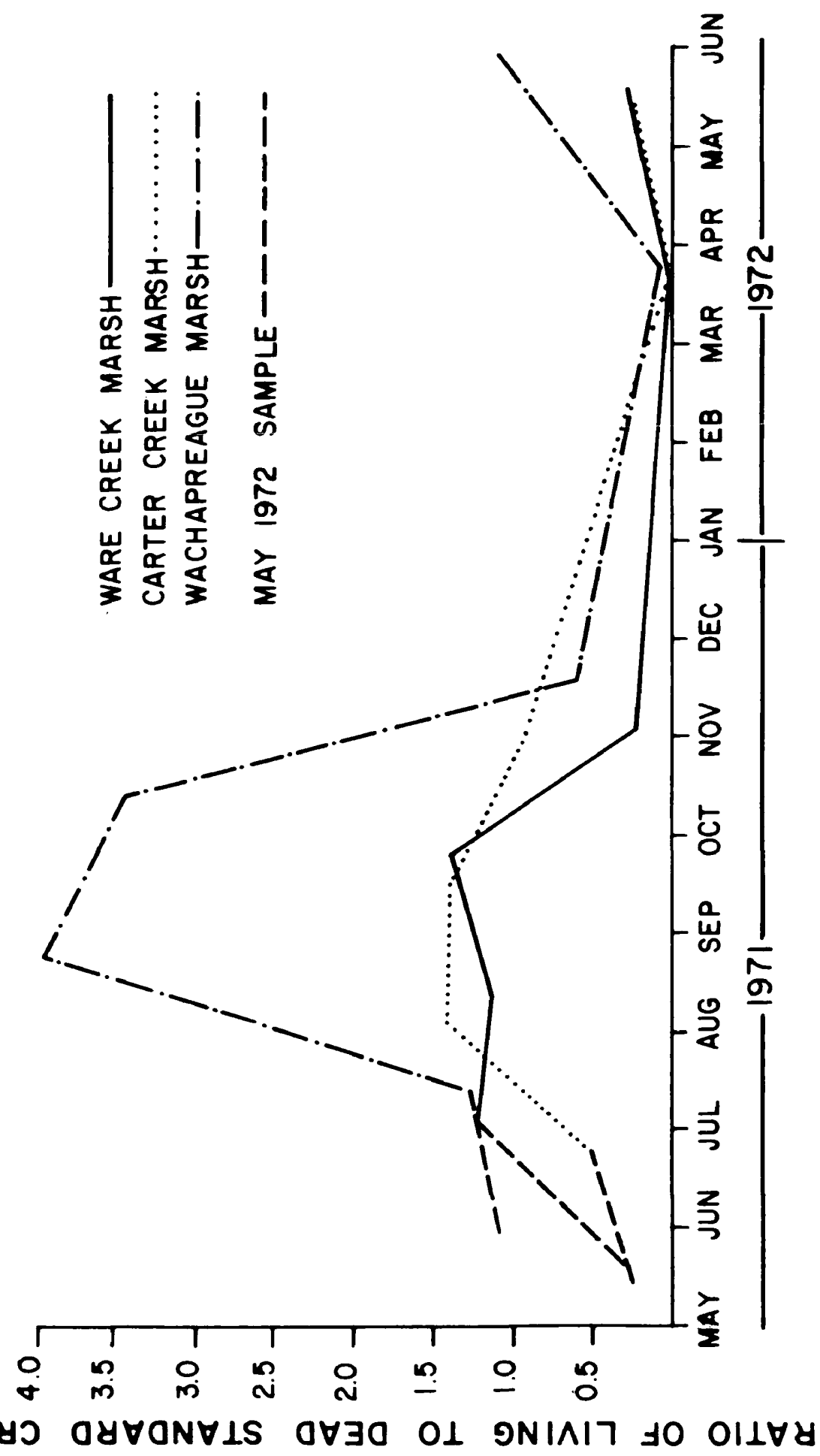


TABLE 8

MEAN VALUE OF SOIL VARIABLES

FROM WARE CREEK, CARTER CREEK AND

WACHAPREAGUE MARSHES $(\bar{X} \pm 1 \mathrm{SE})$

\section{Marsh}

Edaphic

Parameters

Ware Creek

Carter Creek

Wachapreague

Total Kjeldah1

$6347 \pm 535$

$7564 \pm 814$

$1990 \pm 122$

Total Phosphorus

$910 \pm 42$

$814 \pm 35$

$620 \pm 15$

(ppm)

Magnesium (ppm)

$5094 \pm 265$

$8821 \pm 840$

$7316 \pm 357$

Potassium (ppm)

$3840 \pm 218$

$6136 \pm 766$

$4306 \pm 216$

Calcium (ppm)

$478 \pm 183$

$2016 \pm 744$

$417 \pm 30$

$\mathrm{pH}$

$6.1 \pm 0.1$

$6.2 \pm 0.1$

$6.7 \pm 0.1$

Salinity (o/oo)

$4.4 \pm 0.4$

$11.3 \pm 0.7$

$31.5 \pm 0.5$ 
to Ware Creek Marsh, while $\mathrm{K}$ and $\mathrm{Ca}$ concentrations were significantly higher (Appendix, Tables $A 6$ and $A 7$, respectively) in Carter Creek Marsh relative to the others.

\section{Correlation Between Soil Parameters}

Correlation matrices of soil parameters in Ware Creek, Carter Creek, and Wachapreague Marshes sampled during the period of peak living standing crop are given in Tables 9, 10, and 11. Table 12 presents the correlation matrix for the combined data of the three marshes. Consistent significant correlations were found between $\mathrm{Mg}$ and $\mathrm{K}, \mathrm{pH}$ and $\mathrm{TKN}$, and $\mathrm{Ca}$ and $\mathrm{TKN}$, while $\mathrm{Ca}$ and $\mathrm{TP}$, and $\mathrm{Ca}$ and $\mathrm{Mg}$ were generally significantly correlated.

\section{Soil TKN/TP Ratios}

The soil TKN/TP ratios were significantly different (Appendix, Table A8) in each marsh. TKN/TP ratios in Wachapreague, Ware Creek, and Carter Creek Marshes were 3.5, 7.2, and 9.6, respectively.

\section{Variations During the Growing Season}

Variations in the concentration of soil nutrients, $\mathrm{pH}$, salinity, and precipitation in Ware Creek, Carter Creek, and Wachapreague Marshes throughout the growing season are shown in Figures 10, 11, and 12. In general, precipitation seemed to most influence cation concentrations, while TKN and TP levels were regulated by another phenomenon (see DISCUSSION) . 


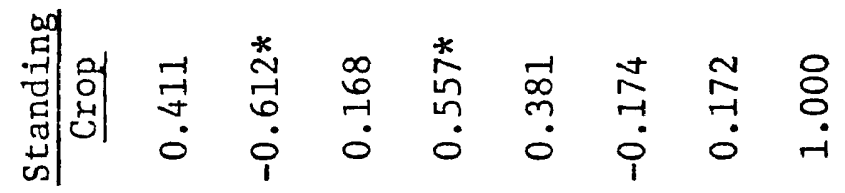

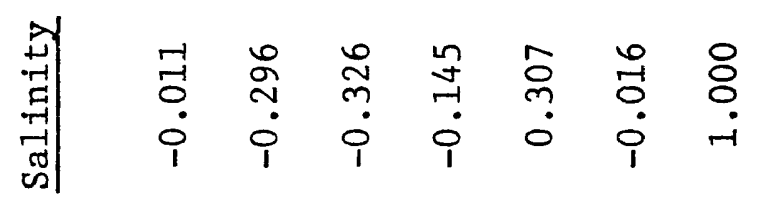

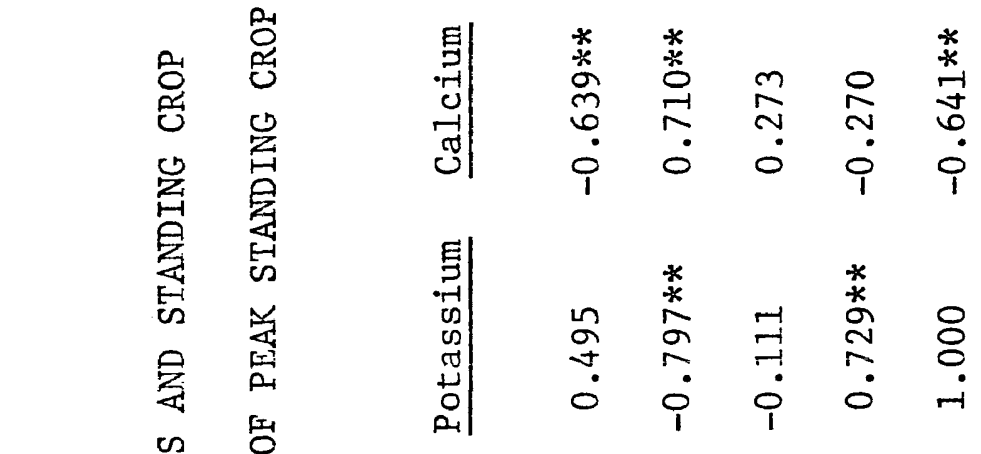

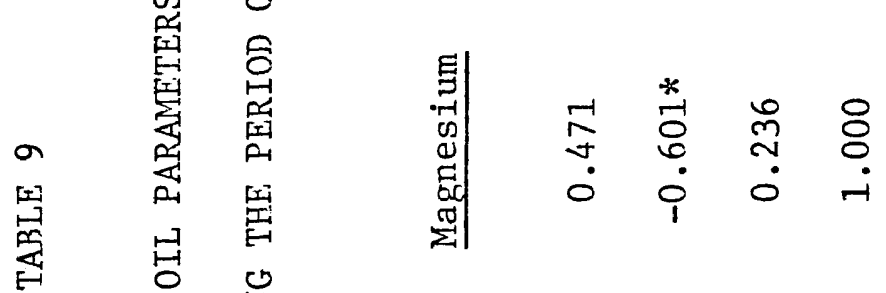

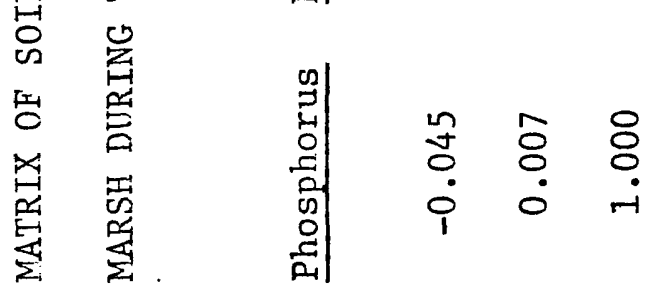

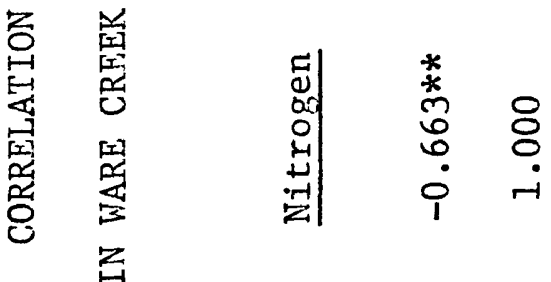

$$
\begin{aligned}
& \text { 뎽 용 } \\
& \text { 㸚| }
\end{aligned}
$$

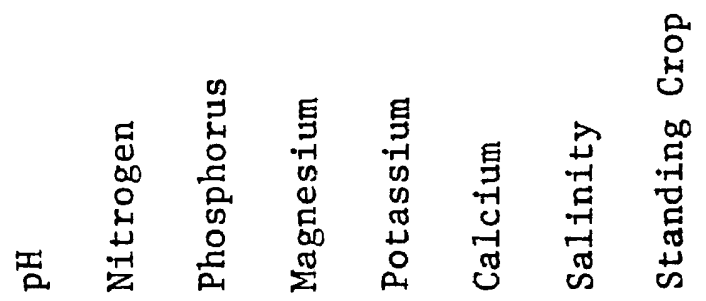




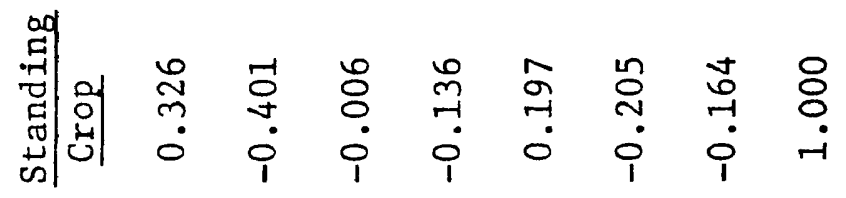

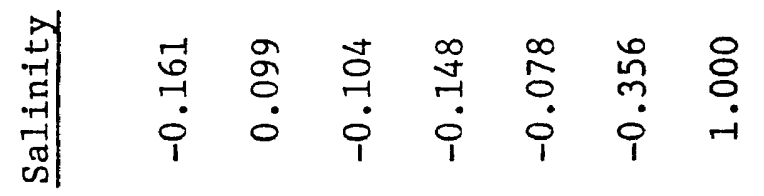

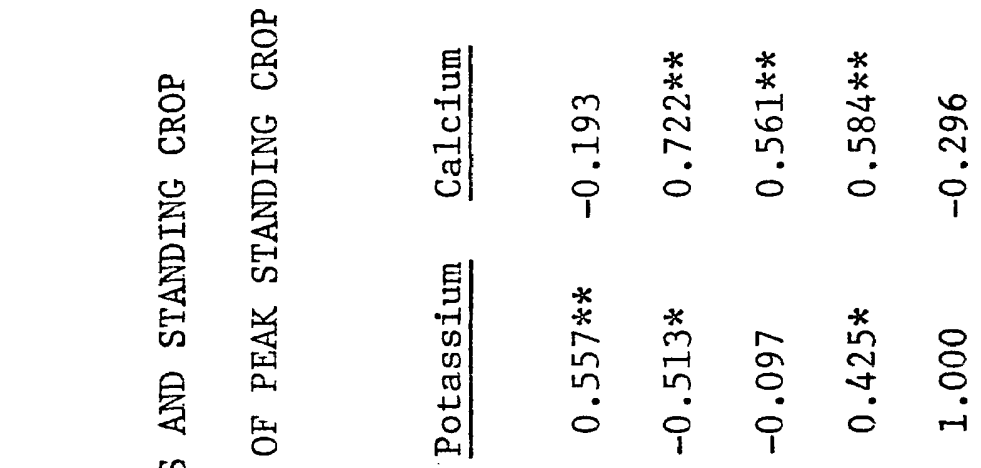

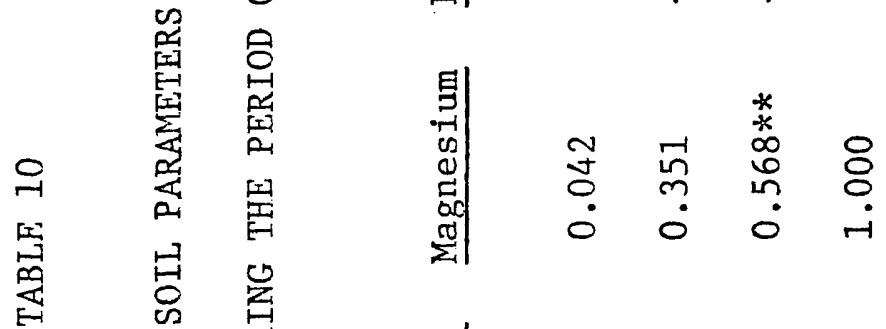

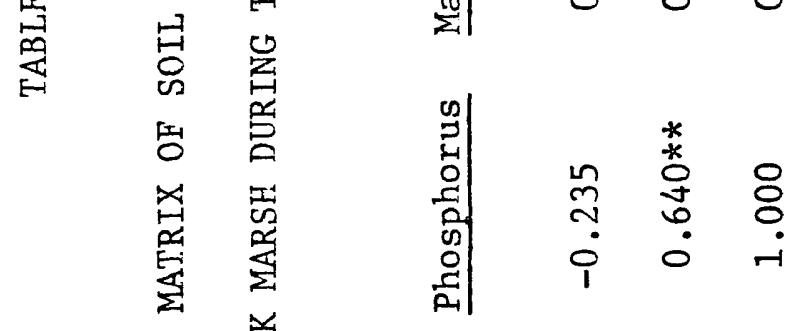

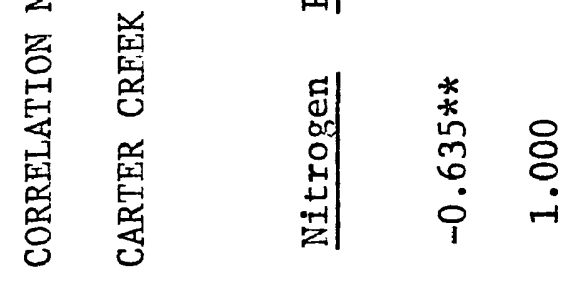

$$
\begin{aligned}
& \text { 落 }
\end{aligned}
$$

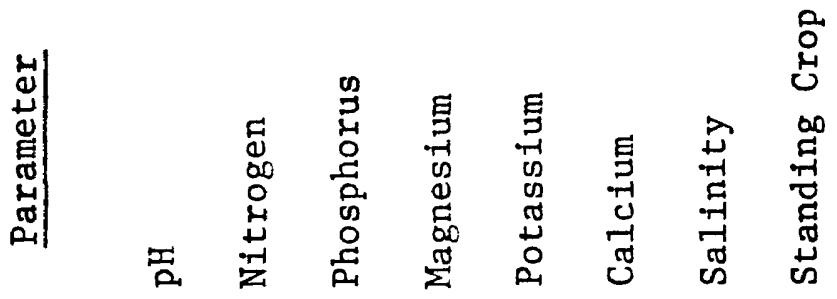




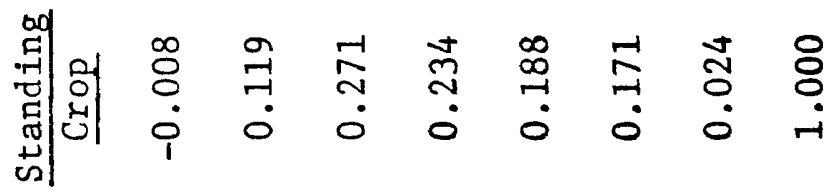

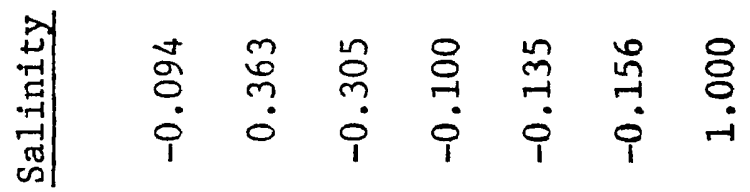

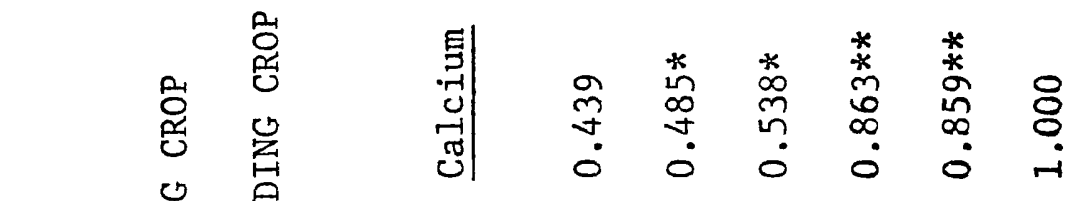

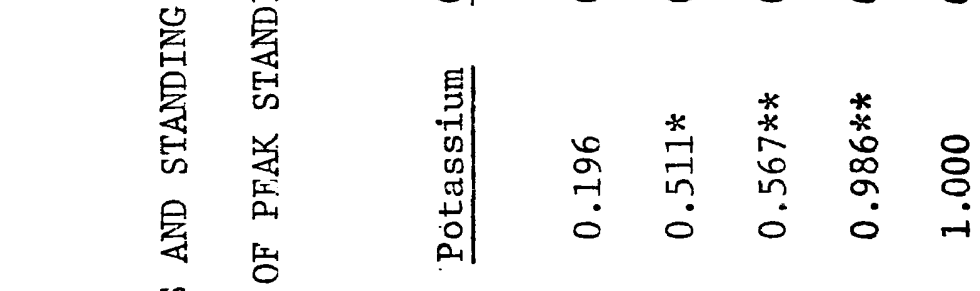

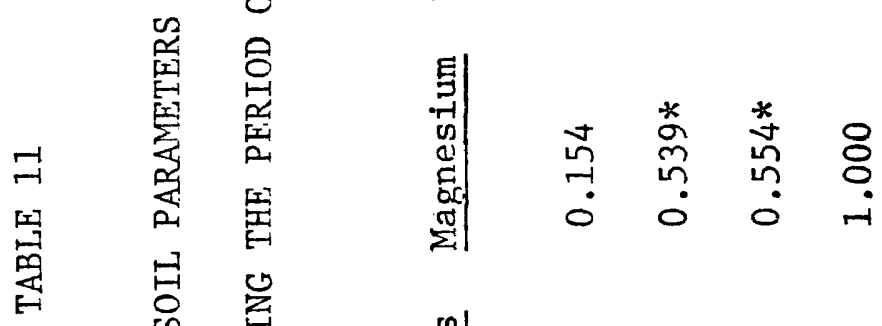

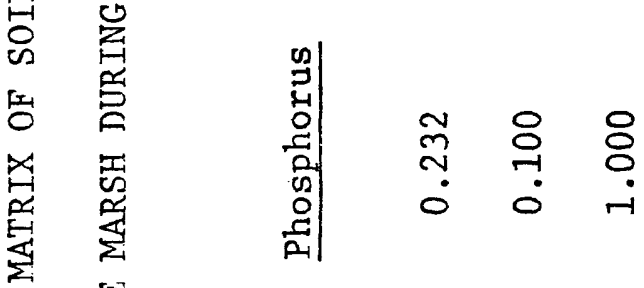

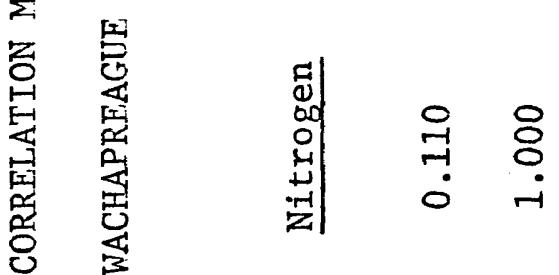

$$
\begin{aligned}
& \text { 省 究 } \underset{8}{8} \\
& \text { 梁. }
\end{aligned}
$$

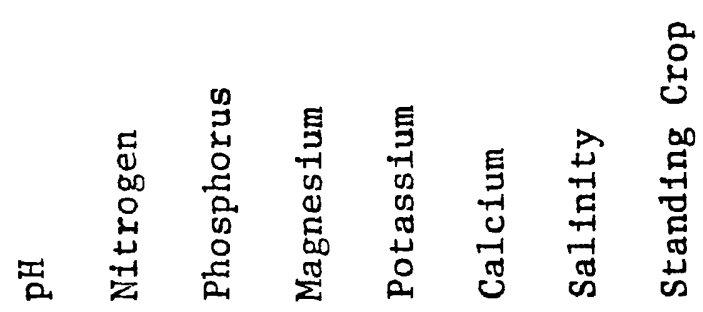




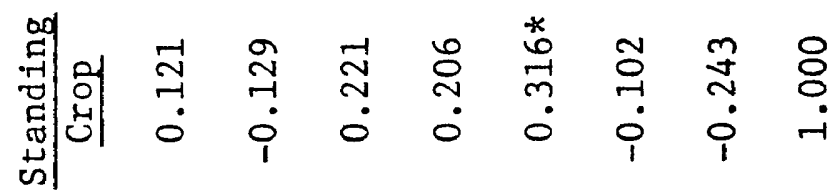

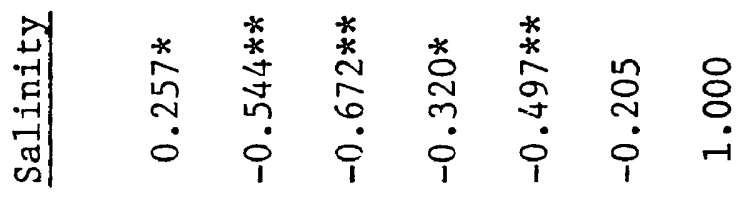

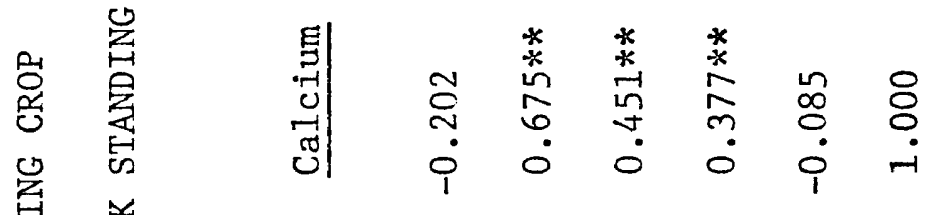

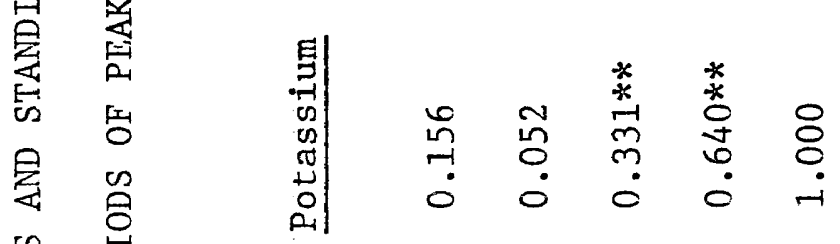

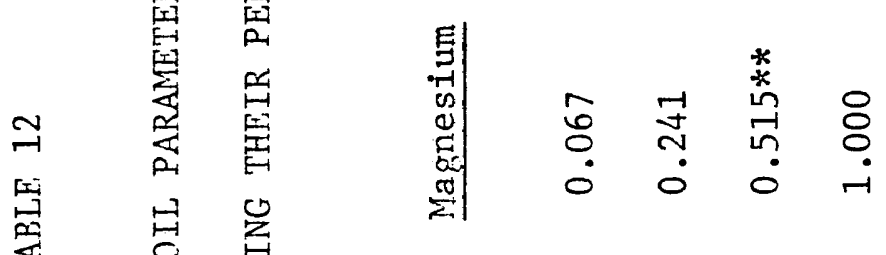

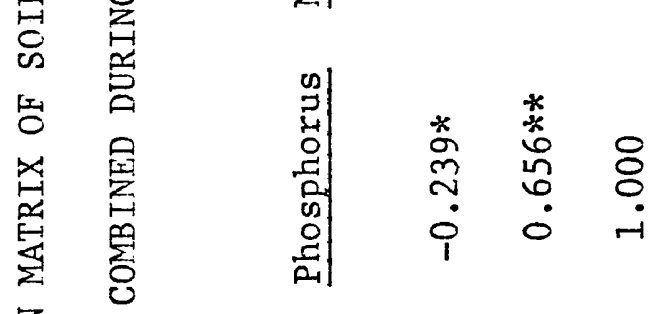

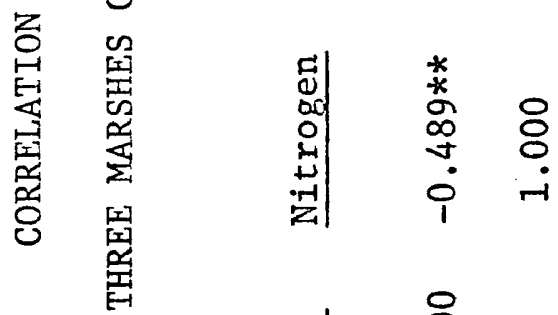

$$
\begin{aligned}
& \text { 畐 票 品 }
\end{aligned}
$$

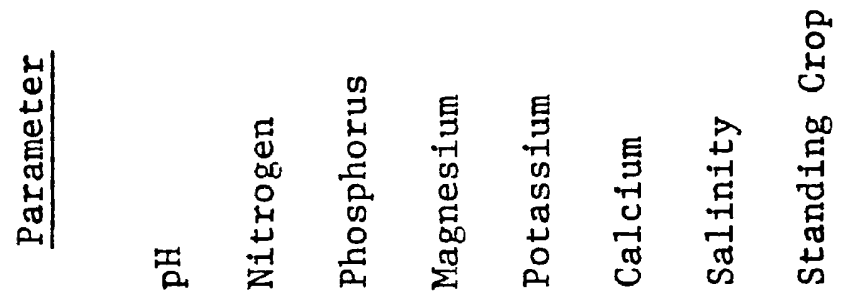


Figure 10. Variation in selected soil and environmental parameters in Ware Creek Marsh during the growing season.

Vertical lines represent 1SE. Standard errors were not available for precipitation. 


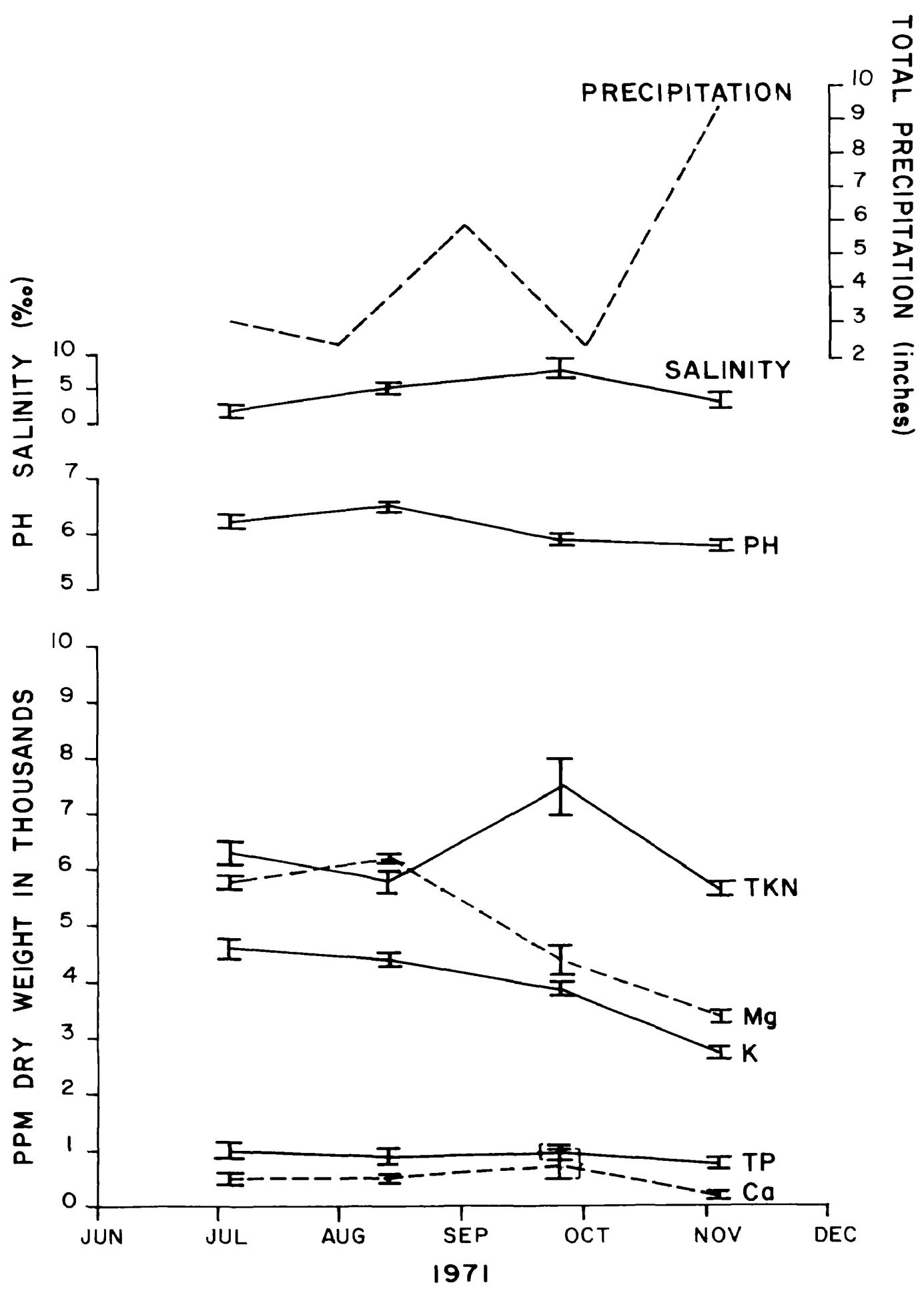


Figure 11. Variation in selected soil and environmental parameters in Carter Creek Marsh during the growing season.

Vertical lines represent 1SE. Standard errors were not available for precipitation. 


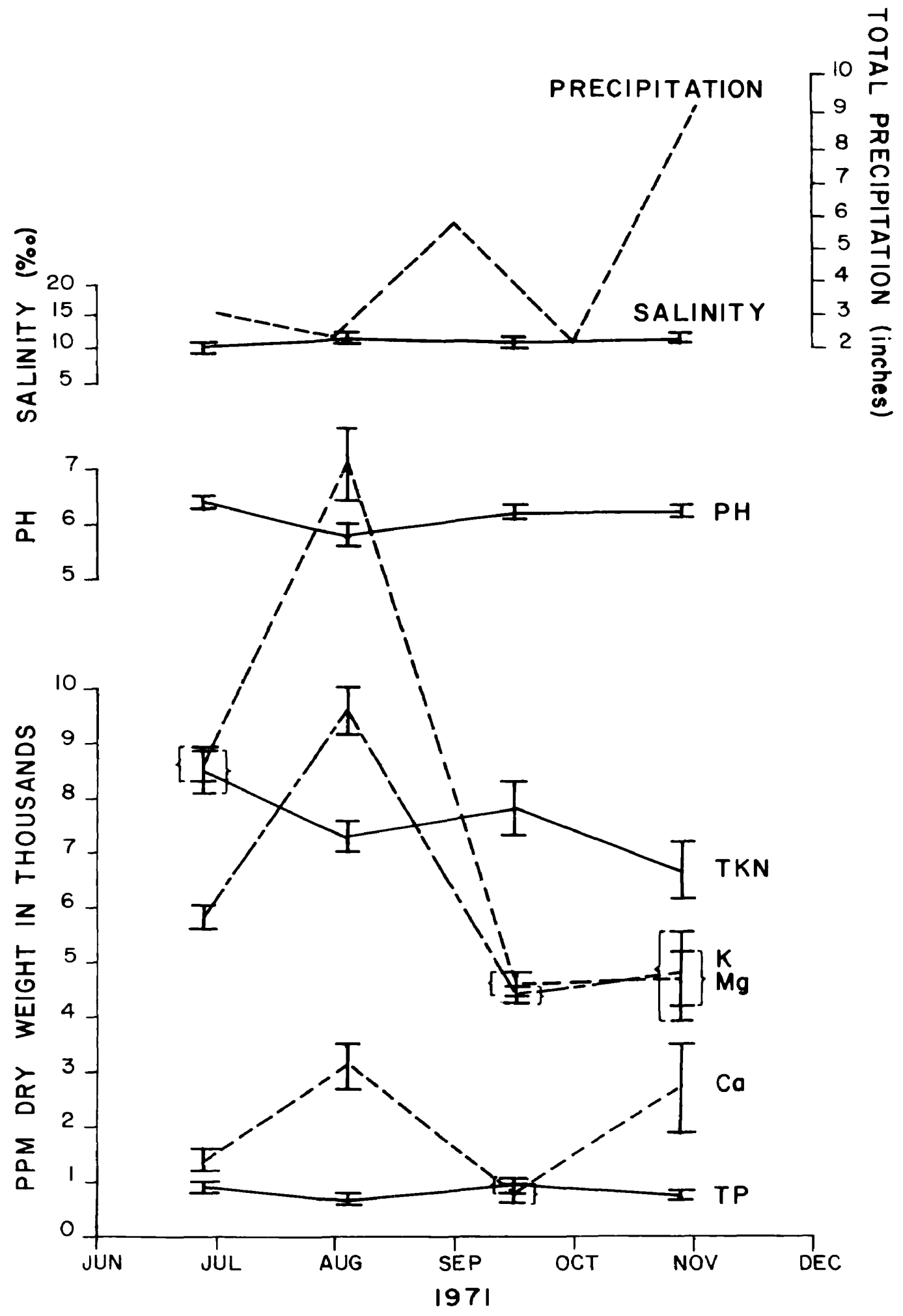


Figure 12. Variation in selected soil and environmental parameters in Wachapreague Marsh during the growing season.

Vertical lines represent 1SE. Standard errors were not available for precipitation. 


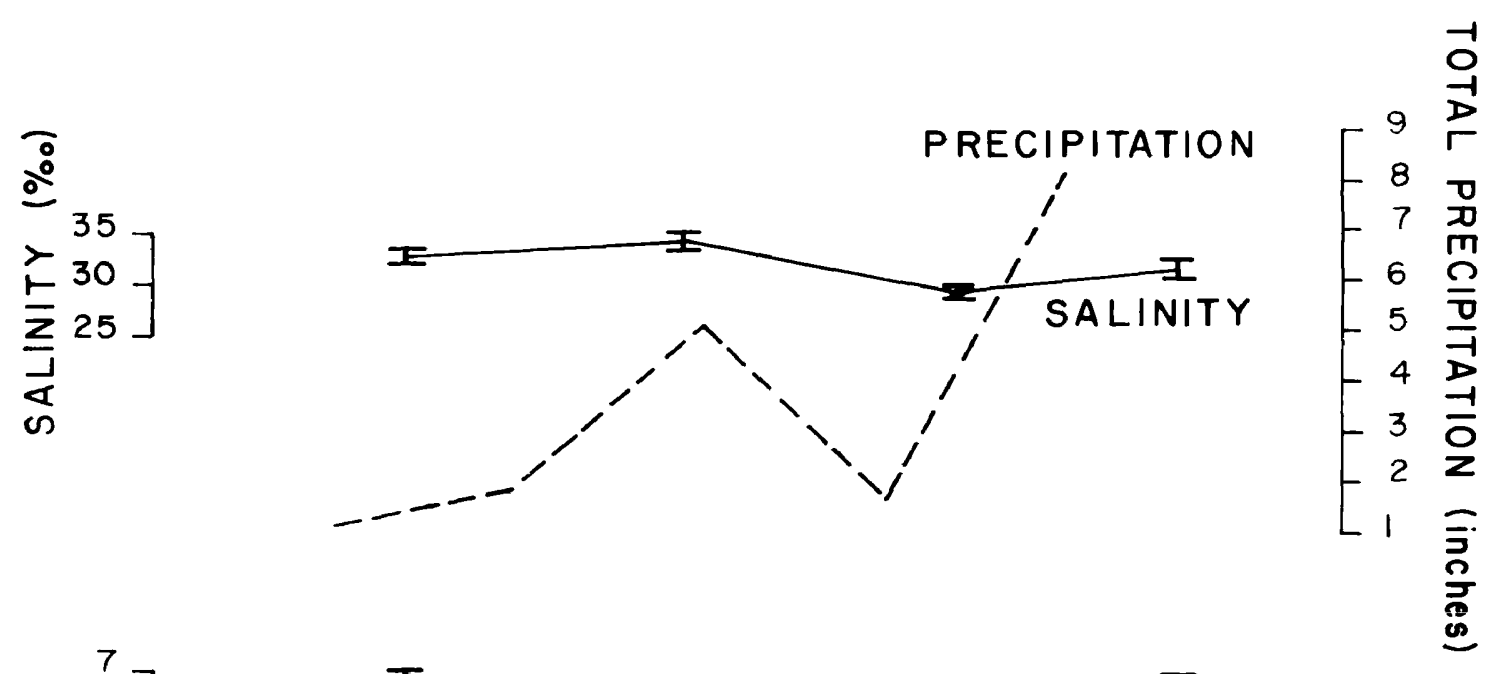

$\left.\begin{array}{ll}7 & 7 \\ \hdashline & 6\end{array}\right]$
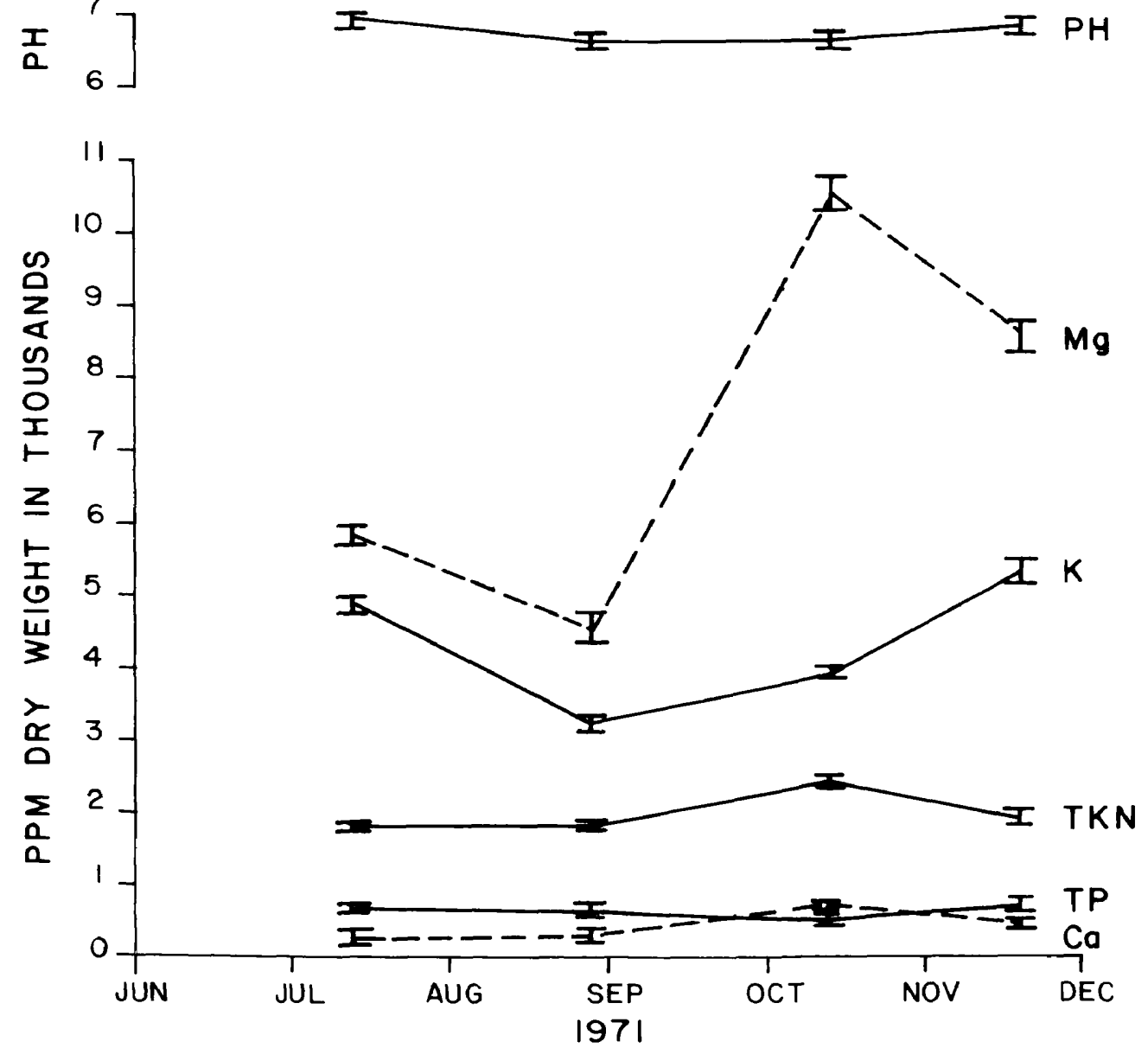
Nitrogen and Phosphorus

Concentrations in Spartina alterniflora

\section{Mean Concentrations}

While there was no significant difference (Appendix, Table A9) in plant TKN (Table 13) among the three marshes, there was a significant difference (Appendix, Table Al0) in plant TP (Table 13) between Wachapreague and Ware Creek Marshes. Although plant TKN and TP were significant1y correlated in Ware Creek and Wachapreague Marshes $(r=0.52$, d.f. $=17$ and $r=0.44$, d.f. $=20$, respectively), plant TKN and $\mathrm{TP}$ were not significantly correlated $(r=0.28$, d.f. $=20)$ in Carter Creek Marsh.

\section{Spartina alterniflora TKN/TP Ratios}

There was no apparent trend in plant TKN/TP ratios in Wachapreague Marsh during the growing season. The mean plant TKN/TP ratio at the time of peak standing crop in Wachapreague Marsh (9.6) was significantly different (Appendix, Table A11) from that in Carter and Ware Creek Marshes (7.8 and 7.6 , respectively) at approximately the same time. Carter and Ware Creek Marshes' TKN/TP ratios were not significantly different (Appendix, Table Al1).

Variations During the Growing Season

TKN and TP of $\underline{S}$. alterniflora tissue were highest in the spring (1.5\% dry weight and $0.16 \%$ dry weight, respectively) and gradually decreased to a low in the fall (1.03\% and $0.09 \%$, respectively), (Fig. 13). 
TABLE 13

MEAN SPARTINA ALTERNIFLORA TOTAL KJELDAHL NITROGEN AND TOTAL PHOSPHORUS CONCENTRATION DURING PEAK STANDING CROP $(\overline{\mathrm{X}} \pm 1 \mathrm{SE})$

Marsh

P1ant Nutrient

Total Kjeldahl Nitrogen (ppm)

Total Phosphorus

\begin{abstract}
Nitrogen (ppm)
\end{abstract}

$$
\text { Ware Creek }
$$

$10,393 \pm 538$

$9,243 \pm 340$

Carter Creek

Wachapreague

Total Phosphorus

\begin{abstract}
$1,358 \pm 77$
\end{abstract}
$1,123 \pm 70$ 
Figure 13. Variation in total Kjeldahl nitrogen and total phosphorus of Spartina alterniflora in Wachapreague Marsh.

Vertical lines represent $1 \mathrm{SE}$. 


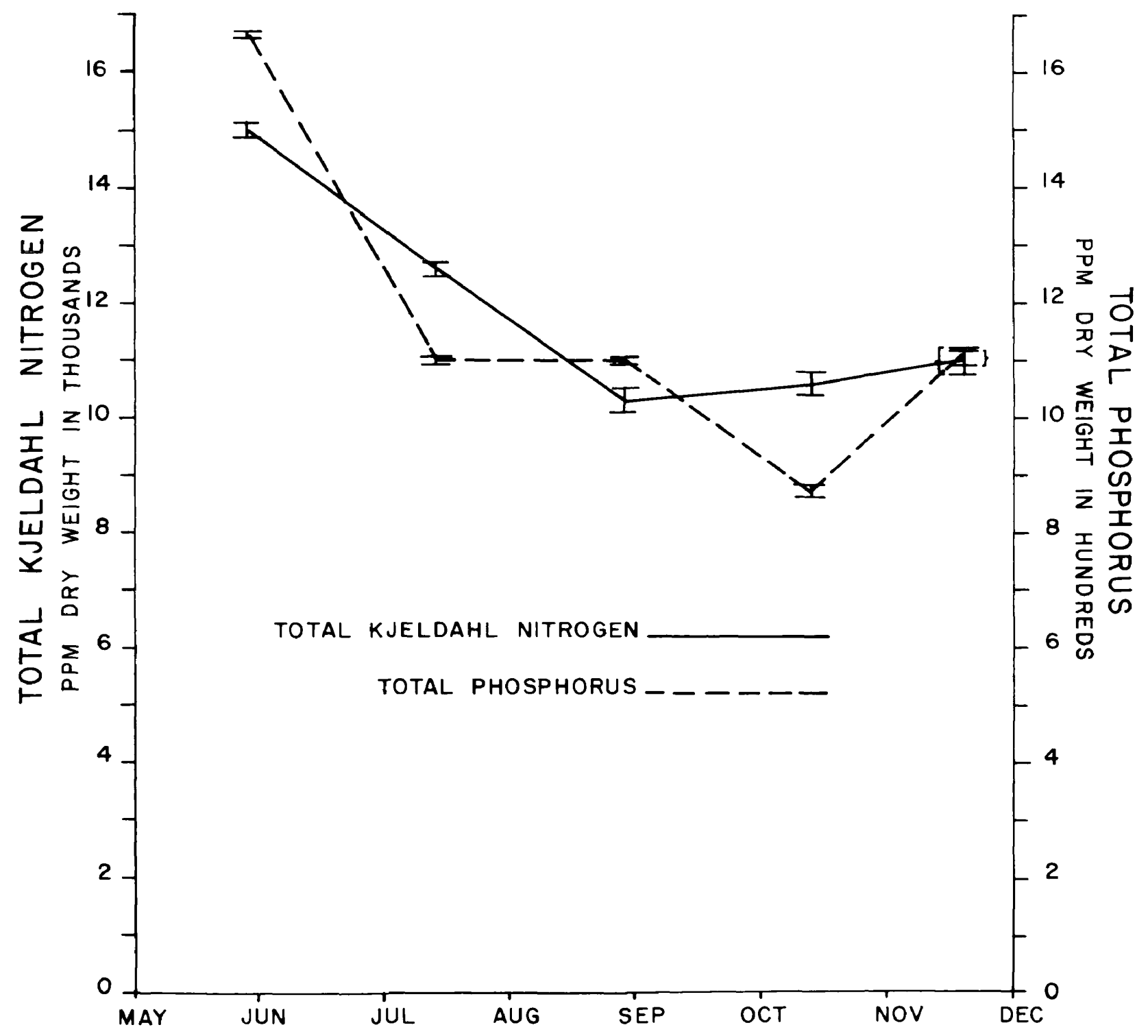


Relationship Between Spartina alterniflora TKN and TP Concentrations and Soil Levels

There was no significant correlation between plant and soil TKN in Ware Creek, Carter Creek and Wachapreague Marshes $(r=-0.50$, d.f. $=8 ; \mathrm{r}=0.03, \mathrm{~d} . \mathrm{f} .=19 ; \mathrm{r}=-0.18, \mathrm{~d} . \mathrm{f} .=19$, respectively) or between plant and soil TP $(r=-0.48$, d.f. $=8 ; r=-0.01$, d.f. $=17$; $\mathbf{r}=-0.06$, d.f. $=20$; respectively) at peak standing crop. There was also no significant correlation between plant TKN/TP and soil TKN/TP ratios in Ware Creek, Carter Creek, and Wachapreague Marshes $(r=0.55$, d.f. $=9 ; r=-0.44$, d.f. $=16 ; r=0.05$, d.f. $=18 ;$ respectively) at peak standing crop.

\section{Soil Parameters and Standing Crop}

There were no significant correlations between standing crop and soil nutrient concentrations in Carter Creek or Wachapreague Marshes (Tables 10 and 11 , respectively). However, there was a significant negative correlation between standing crop and nitrogen and a significant positive correlation between standing crop and magnesium in Ware Creek Marsh (Table 9). The combined data from the three marshes resulted in a significant positive correlation between potassium and standing crop (Table 12).

Tables 14,15 , and 16 give the multiple $\mathrm{R}^{2}$ values (coefficients of determination) for Ware Creek, Carter Creek, and Wachapreague Marshes. The $\mathrm{R}^{2}$ values for the combined data are shown in Table 17 . Nitrogen accounted for the greatest variation in standing crop in Ware and Carter Creek Marshes, while phosphorus was most important in Wachapreague Marsh. However, when the data from all the marshes were combined, potassium and nitrogen accounted for the greatest variation in standing crop. 
TABLE 14

MULTIPLE REGRESSION OF PFAK STANDING CROP ON SOIL PARAMETERS IN WARE CREEK MARSH

MULTIPLE

Step Number

1

2

3

4

5

Parameter
Nitrogen
Calcium
Magnesium
Potassium
Salinity

$\underline{\mathbf{R}}$

0.6125

0.7163

0.7296

0.7698

0.7971

$\mathrm{R}^{2}$

0.3751

0.5131

0.5324

0.5925

0.6354
INCREASE

in $\mathrm{R}^{2}$

0.3751

0.1380

0.0193

0.0602

0.0428 
TABLE 15

MULTIPLE REGRESSION OF PEAK STANDING CROP ON SOIL PARAMETERS IN CARTER CREEK MARSH

\begin{tabular}{|c|c|c|c|c|}
\hline \multirow[b]{2}{*}{ Step Number } & \multirow[b]{2}{*}{ Parameter } & \multicolumn{2}{|c|}{ MULTIPLE } & \multirow{2}{*}{$\begin{array}{l}\text { INCREASE } \\
\text { in } \mathrm{R}^{2} \\
\end{array}$} \\
\hline & & $\mathbf{R}$ & $\mathrm{R}^{2}$ & \\
\hline 1 & Nitrogen & 0.4006 & 0.1605 & 0.1605 \\
\hline 2 & Phosphorus & 0.5165 & 0.2668 & 0.1063 \\
\hline 3 & Magnesium & 0.5441 & 0.2960 & 0.0292 \\
\hline 4 & Calcium & 0.5688 & 0.3235 & 0.0275 \\
\hline 5 & Potassium & 0.5729 & 0.3282 & 0.0046 \\
\hline 6 & Salinity & 0.5754 & 0.3311 & 0.0029 \\
\hline
\end{tabular}


TABLE 16

MULTIPLE REGRESSION OF PEAK STANDING CROP

ON SOIL PARAMETERS IN WACHAPRFAGUE CREEK MARSH

\begin{tabular}{clccc} 
& & \multicolumn{2}{c}{ MULTIPLE } & \multicolumn{2}{c}{ INCREASE } \\
Step Number & Parameter & $\mathrm{R}$ & $\frac{\mathrm{R}^{2}}{\text { in } \mathrm{R}^{2}}$ \\
\hline 1 & Phosphorus & 0.2709 & 0.0734 & 0.0734 \\
2 & Salinity & 0.2930 & 0.0859 & 0.0125 \\
3 & Magnesium & 0.3069 & 0.0942 & 0.0083 \\
4 & Potassium & 0.4071 & 0.1657 & 0.0716 \\
5 & Calcium & 0.4113 & 0.1692 & 0.0035
\end{tabular}




\section{TABLE 17}

MULTIPLE REGRFSSION OF PFAK STANDING CROP

ON SOIL PARAMETERS IN WARE, CARTER, AND WACHAPRFAGUE MARSHES

MULTIPLE

\begin{tabular}{cl} 
Step Number & Parameter \\
\hline 1 & Potassium \\
2 & Nitrogen \\
3 & Phosphorus \\
4 & Salinity \\
5 & Calcium \\
6 & Magnesium
\end{tabular}

$\frac{R}{0.3163}$
0.3483
0.4613
0.4796
0.4814
0.4826

INCREASE

$\frac{\text { in } \mathrm{R}^{2}}{0.1000}$
0.0213
0.0915
0.0171
0.0018
0.0012


DISCUSSION

\section{Community Composition and Salinity}

Plant species from Carter and Ware Creek Marshes were clustered into associations which were best defined by the species salinity tolerance. Ware Creek's Association A contained species whose tolerance for moderate salinity stress was greater than that of species of Association B. Association A was further divided on the basis of salinity tolerance into two subassociations, $A_{1}$ and $\mathrm{A}_{2}$. Species of subassociation $\mathrm{A}_{2}$ are generally restricted to higher salinity marshes than those of subassociation $A_{1}$ (Palmisano, 1970). Spartina alterniflora, considered to be a high salinity salt marsh species, was grouped with the freshwater subassociation $A_{1}$ which substantiated the laboratory findings that $\underline{S}$. alterniflora can grow (Gosselink, 1970) and germinate (Mooring et al., 1971) better in low salinity or freshwater cultures than in high salinity environments. Therefore, it is not surprising to find this species associated with what are generally considered freshwater marsh plants.

The two associations making up the plant community of Carter Creek Marsh were also separated according to salinity tolerance. In contrast to its association in Ware Creek Marsh, Spartina alterniflora demonstrated its ability to withstand higher salinity environments by being associated 
with the more salt tolerant species. This species' euryhaline tolerance is further realized in euhaline Wachapreague Marsh, where high salinity levels prevent most marsh plants from growing.

The wide range of saline environments inhabited by $\underline{S}$. alterniflora Is additional evidence to support the claims of Adams (1963), Gosselink (1970), and Phleger (1971) that Spartina is a facultative halophyte growing in fresh and saltwater environments alike.

Salinity and salinity-associated factors such as tidal submergence and surface elevation, have long been considered the primary agents in delineating the distribution and association of salt marsh plants (Harshberger, 1911; Keith, 1958; Adams, 1963; Ranwe11 et a1., 1964). The association of plants based on species' salinity tolerance in Carter and Ware Creek Marshes is further evidence of this fact. Relative Dominance Values provided a good way of delineating the type of marsh to which a species is best adapted, as for example: 1) highly saline tolerant Spartina alterniflora was more dominant in euhaline Wachapreague marsh than in Carter and Ware Creek Marshes, and 2) S. patens and Distichlis spicata which are also salt tolerant species (Palmisano, 1970) were considerably more dominant in Carter Creek Marsh than less saline tolerant species such as Scirpus spp. and Juncus spp. which were more dominant in Ware Creek Marsh.

\section{Annual Salt Marsh Primary Production}

\section{The Production of Virginia Marshes}

Even though many of the marshes along the Eastern Coast of the United States contain the same or similar species of plants, there is, as previously mentioned, considerable latitudinal variation in their 
annual productions. This geographical difference has been attributed to a longer growing season in the more southernly marshes (Morgan, 1961; Kirby, 1971).

The net primary production values for Ware Creek and Carter Creek Marshes fit very well into this latitudinal gradient of marsh production (Table 18), even though the Wachapreague Marsh value is somewhat lower than one would expect. This range of salt marsh production, $362 \mathrm{~g} / \mathrm{m}^{2}$ to $572 \mathrm{~g} / \mathrm{m}^{2}$ is similar to what Keefe and Boynton (1973) determined $\left(427 \mathrm{~g} / \mathrm{m}^{2}-558 \mathrm{~g} / \mathrm{m}^{2}\right)$ for the peak standing crop of salt marshes surrounding Chincoteague Bay, Maryland-Virginia.

Keefe and Boynton's standing crop value of $427 \mathrm{~g} / \mathrm{m}^{2} \pm 90$ for a community consisting of tall and short form Spartina alterniflora is within one standard error of the value for vegetatively similar Wachapreague Marsh.

Salt marsh production values, determined by the frequent harvest method, have thus far not exceeded $1500 \mathrm{~g} / \mathrm{m}^{2} \mathrm{yr}$. Kirby (1971) using both Smalley's method and a productivity method, which accounts for material lost by tidal flushing between sampling periods, found that the latter method doubled his estimate of a streamside $\underline{\text { s. alterniflora }}$ marsh from $1410 \mathrm{~g} / \mathrm{m}^{2}$ to $2857 \mathrm{~g} / \mathrm{m}^{2}$. If Kirby's method is valid, marsh production measurements along the East Coast have been underestimated by as much as $100 \%$.

The Growing Season of Fresh versus Salt Marshes

Although the length of the growing season along the East Coast varies, the time of peak salt marsh production is very nearly the same, late August through September (Waits, 1967; Williams and Murdoch, 1969; 
TABLE 18

\author{
COMPARISON OF ANGIOSPERM PRODUCTION VALUES \\ OF SOME EASTERN UNITED STATES
}

SALT MARSHES

\begin{tabular}{|c|c|c|}
\hline Location & Production $\left(\mathrm{g} / \mathrm{m}^{2} \mathrm{yr}\right)$ & Reference \\
\hline New Jersey & $\begin{array}{l}268 \\
369\end{array}$ & $\begin{array}{l}\text { (Good, 1965) } \\
\text { (Durand and Nadeau, 1972) }\end{array}$ \\
\hline Delaware & 445 & (Morgan, 1965) \\
\hline $\begin{array}{l}\text { Maryland } \\
\text { Maryland-Virginia } \\
\text { Virginia }\end{array}$ & $\begin{array}{c}1218 \\
427-558 \\
361-572\end{array}$ & $\begin{array}{l}\text { (Johnson, 1970) } \\
\text { (Keefe and Boynton, 1973) } \\
\text { (Author) }\end{array}$ \\
\hline North Carolina & $\begin{array}{c}650 \\
329-1296 \\
1189\end{array}$ & $\begin{array}{l}\text { (Williams and Murdoch, 1969) } \\
\text { (Stroud and Cooper, 1969) } \\
\text { (Waits, 1967) }\end{array}$ \\
\hline Georgia & 973 & (Smalley, 1958) \\
\hline Louisiana & 1200 & (Kirby, 1971) \\
\hline
\end{tabular}


Stroud and Cooper, 1969; Kirby, 1971, Durand, 1972), which is in agreement with the findings for Wachapreague and Carter Creek Marshes. However, Ware Creek Marsh peaked in early July, almost two months before the others which can be explained by the fact that this marsh community is of the freshwater-oligohaline type. Freshwater emergent species, such as Scirpus americanus and Typha latifolia, reach peak standing crop in llay and June, respectively (Boyd, 1970). Waits (1967) divided his North Carolina marsh into six vegetation types; of these, five matured in the early fall, while Type 5, consisting of several freshwater species, reached peak standing crop in early July. Therefore, the relatively early maturation data of Ware Creek Marsh is not an anomaly, but what should be expected in an oligohaline marsh.

Since freshwater marshes reach their peak standing crop earlier than saltwater marshes, one would expect the initial growth rate of the freshwater marsh to be greater, and indeed, this is verified in the Iiterature (Boyd, 1969, 1970a, 1971). Ware Creek Marsh, whose initial growth rate was double that of either Carter or Wachapreague Marshes, also exhibited this trend. Ware Creek Marsh, even though it had a mean salinity of $40 / 00$ and was twice daily inundated by saline water, was more similar to a freshwater marsh with respect to its growth rate and time of peak standing crop than to a saltwater marsh. 
Dead Standing Crop as a Nutrient Source

The seasonal changes in dead standing crop, which varied inversely with live production and was highest in the winter and lowest in the summer, are typical of regularly flooded salt marshes (Smalley, 1958; Stroud and Cooper, 1969; Kirby, 1971). Large amounts of dead material remain on the marsh during the winter and it is not until the temperature rises in the spring and microbial decomposition begins that the material is gradually degraded and washed out of the marsh (Kirby, 1971), resulting in the lowest dead standing crops in the late summer. Relative to the other marshes, Wachapreague Marsh had significantly less dead material remaining on its surface, which was probably a result of not only a small production, but more importantly, a much larger degree of tidal flushing.

Though there is a large amount of detrital export from a marsh (Odum and de la Cruz, 1967), there is still a considerable amount of dead material remaining on it, even during the summer (Smalley, 1958; Morgan, 1961; Waits, 1967; Stroud and Cooper, 1969; Kirby, 1971). This suggests that not only is the marsh important to the productivity of the estuary, but it also may be the primary nutrient source for its own growth (Maye, 1973). If this is true, Ware and Carter Creek Marshes possess a much larger potential nutrient source to support their own growth than Wachapreague Marsh. This may be an important factor contributing to the low production of this marsh. 
An Index to the Topography of a Marsh

The ratio of living to dead standing crop (L/D) may be used as an index to the topography and degree of flooding of a marsh (Keefe and Boynton, 1973). Regularly flooded salt marshes generally have large L/D ratios (Williams and Murdoch, 1969), while those of irregularly flooded marshes are small (Waits, 1967). The degree and severity of flooding also varies among regularly flooded marshes, and this is reflected in their $L / D$ ratios. Wachapreague Marsh on the Eastern Shore of Virginia is exposed to severe storm tides which remove large amounts of dead material, resulting in a high L/D ratio. Carter and Ware Creek Marshes are part of the York River Estuarine system and are well protected from wave action on storm tides. This was expressed in their low $L / D$ ratios.

Keefe and Boynton (1973) found L/D ratios of irregularly flooded marshes of Chincoteague Bay varying from 0.9 to 2.3 depending on the degree of flooding. In two regularly flooded marshes Morgan (1961), and Williams and Murdoch (1969) derived L/D ratios of 2.2 and 5.5 , respectively, again depending on the degree of flooding. The L/D ratio as an index for characterizing the value of a marsh relative to its detrital contribution to the estuarine system should be further investigated.

Soil Nutrient Concentrations Along a

Salinity Gradient

Although the investigation of soil parameters such as soil nutrients, salinity, and $\mathrm{pH}$ is important for a better understanding of what limits salt marsh production, little data concerning these factors have been collected. Ranwe11 (1964), studying rates of nutrient supply to a 
Great Britain marsh and Chabreck (1972), investigating soil-vegetation relationships in Louisiana marshes, found soil nutrient concentrations to be extremely variable (Table 19). In spite of this variation, one trend common to the Great Britain, Louisiana, and Virginia marshes was a nutrient concentration gradient from freshwater to saltwater marshes and from low to high marsh.

Nitrogen concentrations decreased from freshwater to saltwater marshes, while $\mathrm{Mg}, \mathrm{K}$, and $\mathrm{pH}$ increased. Calcium and $\mathrm{P}$ provided exceptions to the above gradient similarities in that $\mathrm{P}$ increased in the freshwater marshes of Virginia, but decreased in the same type of marshes in Louisiana. Calcium remained relatively constant throughout the gradient in Louisiana, but was quite variable in Virginia.

The higher ionic concentration of seawater increases the soil concentration, resulting in higher soil $\mathrm{Mg}$ and $\mathrm{K}$ in more saline marshes. The data corroborated this to a degree in that cation concentrations were higher in mesohaline Carter Creek Marsh than oligohaline Ware Creek Marsh; however, euhaline Wachapreague Marsh, which one would expect to have the highest cation concentrations, had significantly lower concentrations than Carter Creek Marsh. The higher cation concentrations of Carter Creek Marsh may be a result of outcroping of the Yorktown Formation which is primarily made up of marine molluscan shells.

Nitrogen and phosphorus concentrations are controlled by a completely different phenomenon. From the data collected in this study and Chabreck's (1972), it seems likely that those marshes severely flooded by storm tides retain very little degradable organic matter, and consequently, have lower $\mathrm{N}$ and $\mathrm{P}$ concentrations, while those 
TABLE 19

COMPARISON OF SOIL PARAMETERS

FROM THREE DIFFERENT LOCALITIES

\section{Range (ppt Dry Weight)}

$\begin{array}{lccc}\text { Edaphic Parameters } & \begin{array}{c}\text { Great Britain } \\ \text { (Ranwe11, 1964) }\end{array} & \begin{array}{c}\text { Louisiana } \\ \text { (Chabreck, 1972) }\end{array} & \begin{array}{c}\text { Virginia } \\ \text { (Author) }\end{array} \\ \text { Nitrogen } & 1.1-3.0 & 0.06-2.59 & 1.99-7.56 \\ \text { Phosphorus } & 0.7-1.1 & 0.003-0.17 & 0.62-0.91 \\ \text { Calcium } & 51.1-61.1 & 0.03-7.28 & 0.42-2.02 \\ \text { Magnesium } & - & 0.22-3.22 & 5.1-8.0 \\ \text { Potassium } & 11.0-22.0 & 0.04-0.47 & 3.84-6.14 \\ \text { pH } & - & 3.8-7.7 & 6.1-6.7\end{array}$


marshes having large standing stocks of dead organic matter have high $\mathrm{N}$ and $\mathrm{P}$ concentrations. This theory is also confirmed by Ranwell (1964) and Jeffrey (in Pigott, 1969), who found a gradient in $N$ and $P$ concentrations which increased landward. The high marsh is flooded less frequently and less severely, therefore, more dead organic material is left on the marsh to be degraded, resulting in higher soil $\mathrm{N}$ and $\mathrm{P}$ concentrations.

To my knowledge, there is no data in the literature on salt marsh soil nutrient trends during the growing season. Bayly and o'Neill (1972a, 1972b) studied seasonal ionic fluctuations in freshwater Typha and Phragmites marshes and found that the variation in soil nutrients was so great that no seasonal trends could be determined. This study encountered the same type of extreme variation. Cation concentrations seemed to be highly dependert on precipitation, that is, months of heavy rainfall had lower cation concentrations than months with 1ittle rainfal1. Total phosphorus and TKN showed no discernible trends during the growing season. This may be because the TKN and TP concentrations are not as greatly affected by plant uptake as inorganic forms would be, and therefore, seasonal changes in TKN and TP were not as defined.

Marsh Plant Nutrient and Fnvironmental Concentrations

\section{Seasonal Variation}

Nitrogen and phosphorus concentrations of freshwater marsh plants have a predictable variation during the growing season, that is, concentrations are high in the spring, decrease to a minimum in the summer 
and increase again in the fal1 (Boyd, 1969, 1970a, 1971, Bayly and O'Neil1, 1972a, 1972b). Spartina alterniflora exhibited the same trend in Wachapreague Marsh. Daiber, Gallager, and Sullivan (1970) found evidence in a Delaware $\underline{S}$. alterniflora marsh of the same phenomenon.

Boyd (1969) suggested that the early absorption of nutrients by some aquatic plants would give them competitive advantage over phytoplankton and other angiosperms which cannot absorb nutrients until later in the growing season when optimal conditions exist.

\section{Limiting Nutrients}

Pigott (1969), using Salicornia dolichostachya and Suaeda maritima, demonstrated that less productive plants have lower $\mathrm{N}$ and $\mathrm{P}$ concentrations than more productive ones. In the case of the three marshes in this study, since plant $N$ was not significantly different in each marsh, but plant $P$ had a significantly lower concentration in the less productive Wachapreague Marsh, this suggested that $\mathrm{P}$ was limiting. It should be noted that the nutrients per se might not be in limited supply, but rather sone environmental stress, such as high salinity or low redox potential, may be preventing adequate absorption of nutrients by the plant. This mechanism of nutrient limitation should be further investigated.

High Spartina alterniflora TKN/TP ratios in less productive Wachapreague Marsh suggested that available phosphorus was in lower concentration in this marsh than in Carter or Ware Creek Marshes, implying phosphorus was limiting. 
Correlation Between Plant and Environmental Nutrient Leve1s

There are conflicting results in the literature concerning whether plant nutrient concentrations are proportional to substrate nutrient concentrations (See REVIFW OF LITERATURE). A1though some investigators (Boyd and Hess, 1970; Boyd and Vickers, 1971; Dietz, 1972) have not found strong correlations between tissue and environmental nutrient concentrations, others (Gerloff and Krombholz, 1966; Gossett and Norris, 1971) have. This study corroborated the former researchers in that no significant correlations were found between plant and soil nitrogen or between plant and soil phosphorus. Probably the most important reason for the absence of a significant correlation was that the forms of nitrogen and phosphorus analyzed, total kjeldahl nitrogen and total phosphorus, were not immediately available to the plant. Therefore, high soil nitrogen and phosphorus concentrations did not necessarily mean high plant nitrogen and phosphorus concentrations. There is also the additional problem that the plants absorb nutrients at different rates during the growing season (Boyd, 1969, 1970a; Boyd and Vickers, 1971). Since most of the nutrients will be absorbed before the summer begins, it is likely that if any correlation did exist, it would be negative.

\section{Marsh Standing Crop Relative to Salinity and Soil Mutrients}

In the attempt to specify which edaphic parameters are most important in limiting salt marsh angiosperm production, it was found that the Wachapreague Marsh had significantly lower soil nitrogen 
and phosphorus concentrations, significantly lower plant phosphorus concentrations, significantly higher salinities, and the smallest production relative to Ware and Carter Creek Marshes. This data suggests that high salinity, and low nitrogen and phosphorus concentrations limited the production of Wachapreague Marsh.

This hypothesis is supported by considerable data in the literature. As has been discussed, (see REVIFW OF LITERATURE), marsh grass in the laboratory have lower productivities in higher salinity growth media than in freshwater (Gosselink, 1970; Palmisano, 1970; Phlegher, 1971). With respect to nutrients, phosphorus has been suggested to be limiting to freshwater plants (Boyd and Hess, 1970), while nitrogen is primarily limiting to salt marshes (Pigott, 1969; Stewart et al., 1972; Valiela et al., 1972) with phosphorus secondarily limiting (Pigott, 1969).

Since the TKN concentration of Spartina alterniflora tissue was not significantly different in any of the marshes, but plant TP was significantly lower in the less productive Wachapreague marsh, this suggested that phosphorus and not nitrogen was limiting.

Correlation analysis between standing crop and soil nutrients found very few significant correlations. Although each marsh had different parameters explaining the largest part of variation in standing crop, the following parameters seem to be generally important in all marshes: nitrogen, phosphorus, and at least one cation. $\mathrm{R}^{2}$ values from the multiple regression were small, and therefore, the parameters collectively did not account for a large amount of the 
variation in standing crop. The multiple regression on the combined data from the three marshes showed that potassium and phosphorus accounted for the greatest variation in standing crop.

$\mathrm{R}^{2}$ values were not large enough to draw definite conclusions concerning marsh limiting nutrients. Also, the importance of a factor to growth was variable from one marsh to another. Lanthwel1 et al. (1969) encountered the same problem in trying to define the growth limiting factors of an artificial wild rice marsh. He concluded that since no single variable was consistently related to the differences in plant growth, it did not seem reasonable to specify a particular factor as the one most responsible for the observed variation in production.

In summary, a field study attempting to define the relationships between salt marsh standing crop and soil parameters was inconclusive. It is the author's opinion that the factors limiting salt marsh angiosperm productivity must first be isolated in the laboratory, and then verified in the field using the same techniques. This has yet to be done. 
APPENDIX 
TABLE A1

ANOVA OF MEAN ANNUAL DEAD STANDING CROP

IN WARE CREEK, CARTER CREFK, AND

WACHAPREAGUE MARSHES

\begin{tabular}{lcccc}
\hline Sources of Variation & d.f. & Sum of Squares & Mean Square & $F$ \\
\hline Among Marshes & 2 & 687,018 & 343,509 & $110.23 * *$ \\
Within Marshes & 436 & $1,358,678$ & 3,116 & \\
& & & \\
Total & 438 & $2,045,696$
\end{tabular}

Student-Newman-Keuls' Multiple Range Test:

MARSH

Ware Creek Carter Creek Wachapreague

(g dry weight $\left./ \mathrm{m}^{2}\right) \quad 501 \quad 371 \quad 122$ 
TABLE A2

\begin{abstract}
ANOVA OF LIVING/DEAD STANDING CROP
RATIOS IN WARE CREEK, CARTER CREFK, AND

WACHAPREAGUE MARSIHES AT THE PFRION OF PEAK

LIVING STANDING CROP
\end{abstract}

\begin{tabular}{lcccc}
\hline Sources of Variation & d.f. & Sum of Squares & Mean Square & F \\
\hline Among Marshes & 2 & 5834 & 2917 & $20.39 * *$ \\
Within Marshes & 59 & 8155 & 143 & \\
& & & \\
Total & 61 & 13989
\end{tabular}

Student-Newman-Keuls' Multiple Range Test:

$\underline{\text { MARSH }}$

\begin{tabular}{ccc} 
Ware Creek & Carter Creek & Wachapreague \\
4.39 & 1.71 & 1.60 \\
\hline
\end{tabular}


TABLE A3

\begin{abstract}
ANOVA OF SOIL TKN CONCENTRATIONS IN WARE CREEK, CARTER CREEK, AND WACHAPREAGUE MARSHES
\end{abstract}

\begin{tabular}{lrccc}
\hline Source of Variation & d.f. & Sum of Squares & Mean Square & F \\
\hline Among Marshes & 2 & $1,511,783,061$ & $755,891,530$ & $132.61 * *$ \\
Within Marshes & 253 & $1,442,134,057$ & $5,700,134$ & \\
& & & \\
Total & 255 & $2,953,917,118$
\end{tabular}

Student-Newman-Kuels' Multiple Range Test:

MARSH

Carter Creek Ware Creek Wachapreague

(ppm)

7564

6347 1990 
TABLE A4

ANOVA OF SOIL TP CONCENTRATIONS IN WARE CREEK, CARTER CREEK, AND WACHAPREAGUE MARSHES

\begin{tabular}{lcccc} 
Sources of Variation & d.f. & Sum of Squares & Mean Square & F \\
\hline Among Marshes & 2 & $3,990,124$ & $1,995,062$ & $68.58 * *$ \\
Within Marshes & 263 & $7,650,958$ & 29,091 & \\
& & \\
Total & 265 & $11,641,082$
\end{tabular}

Student-Newman-Keuls' Multiple Range Test:

MARSH

Ware Creek Carter Creek Wachapreague

(ppm) $\quad 910 \quad 814 \quad 620$


TABLE A5

\begin{abstract}
ANOVA OF SOIL MG CONCENTRATIONS
IN WARE CREEK, CARTER CREEK, AND

WACHAPREAGUE, MARSHES
\end{abstract}

\begin{tabular}{lrrrr}
\hline Sources of Variation & d.f. & Sum of Squares & Mean Square & F \\
\hline Among Marshes & 2 & $560,065,787$ & $280,032,893$ & $19.7 * *$ \\
Within Marshes & 264 & $3,752,405,272$ & $14,213,656$ & \\
& & & \\
Total & 266 & $4,312,471,060$
\end{tabular}

Student-Newman-Keuls' Multiple Range Test:

$\underline{\text { MARSH }}$

Carter Creek Wachapreague Ware Creek

\begin{tabular}{lll} 
(ppm) $\quad 8821$ & 7316 & 5094 \\
\hline
\end{tabular}


TABLE A6

\author{
ANOVA OF SOIL $K$ CONCENTRATIONS \\ IN WARE CREEK, CARTFR CREEK, AND \\ WACHAPREAGUE MARSHES
}

\begin{tabular}{lrrrr} 
Sources of Variation & d.f. & Sum of Squares & Mean Square & $F$ \\
\hline Among Marshes & 2 & $245,748,997$ & $122,874,498$ & $19.92 * *$ \\
Within Marshes & 270 & $1,665,542,056$ & $6,168,674$ & \\
& & & \\
Total & 272 & $1,911,291,053$
\end{tabular}

Student-Newman-Keuls' Multiple Range Test:

$\underline{\text { MARSH }}$

Carter Creek Ware Creek Wachapreague

(ppm)

6136

3840

4306 
TABLE A7

ANOVA OF SOIL CA CONCENTRATIONS

IN WARE CREEK, CARTER CREEK, AND

WACHAPREAGUE MARSHES

\begin{tabular}{lrrrr}
\hline Sources of Variation & d.f. & Sum of Squares & Mean Square & F \\
\hline Among Marshes & 2 & $124,968,739$ & $62,484,369$ & $19.05 * *$ \\
Within Marshes & 268 & $879,252,139$ & $3,280,791$ & \\
& & & \\
Total & 270 & $1,004,220,878$
\end{tabular}

Student-Newman-Keuls' Multiple Range Test:

MARSH

Carter Creek Ware Creek Wachapreague

\begin{tabular}{ll} 
(ppm) $\quad 2016$ & 478 \\
\hline
\end{tabular}


TABLE A8

ANOVA OF SOIL TKN/TP RATIOS

IN WARE CREEK, CARTER CRFEK, AND

WACHAPREAGUT MARSHES

\begin{tabular}{lcccc}
\hline Sources of Variation & d.f. & Sum of Squares & Mean Square & F \\
\hline Among Marshes & 2 & 11271 & 5635 & $126.69 * *$ \\
Within Marshes & 246 & 10943 & 44 & \\
& & & \\
Total & 248 & 2214
\end{tabular}

Student-Newman-Keuls' Multiple Range Test:

MARSH

\begin{tabular}{ccc} 
Carter Creek & Ware Creek & Wachapreague \\
9.04 & 7.17 & 3.41 \\
\hline
\end{tabular}


TABLE A9

ANOVA OF SPARTINA ALTERNIFLORA

TKN CONCENTRATIONS IN WARE CREEK,

CARTER CREEK, AND VACHAPREAGUE MARSHES

\begin{tabular}{lcccc}
\hline Sources of Variation & d.f. & Sum of Squares & Mean Square & F \\
\hline Among Marshes & 2 & $16,348,181$ & $8,174,090$ & 2.12 \\
Within Marshes & 59 & $227,590,336$ & $3,857,463$ & \\
& & & \\
Total & 61 & $243,938,517$
\end{tabular}


TABLE A10

ANOVA OF SPARTINA ALTFRNIFLORA

TP CONCENTRATIONS IN WARE CREEK,

CARTER CREEK, AND WACHAPREAGUE MARSHES

\begin{tabular}{lcccc}
\hline Sources of Variation & d.f. & Sum of Squares & Mean Square & $F$ \\
\hline Among Marshes & 2 & 634,205 & 317,102 & $3.37 *$ \\
Within Marshes & 59 & $5,654,388$ & 94,142 & \\
& & & \\
Total & 61 & $6,188,593$
\end{tabular}

Student-Newman-Keuls' Multiple Range Test:

$\underline{\text { MARSH }}$

Ware Creek Carter Creek Wachapreague

(ppm)

1358

1123

1114 
TABLE A11

\author{
ANOVA OF SPARTINA ALTERNIFLORA \\ TKN/TP RATIOS IN WARE CREEK, \\ CARTER CREEK, AND WACHAPREAGUE MARSHES
}

\begin{tabular}{lcccc}
\hline Sources of Variation & d.f. & Sum of Squares & Mean Square & $F$ \\
\hline Among Marshes & 2 & 217 & 108.50 & $7.25 * *$ \\
Within Marshes & 55 & 823 & 14.96 & \\
& & & \\
Total & 57 & 1040
\end{tabular}

Student-Newman-Keuls' Multiple Range Test:

\title{
$\underline{\text { MARSH }}$
}

\begin{tabular}{ccc} 
Wachapreague & Ware Creek & Carter Creek \\
9.55 & 7.78 & 7.43 \\
\hline
\end{tabular}




\section{LITERATURE CITED}

Adams, D. A. 1963. Factors influencing vascular plant zonation in North Carolina salt marshes. Ecol. 44:445-566.

Adams, S. M. and J. W. Angelovic. 1970. Assimilation of detritus and its associated bacteria by three species of estuarine animals. Ches. Sci. 11:249-254.

American Instrument Co., Inc. 1959. The determination of nitrogen by the kjeldahl procedure including digestion, distillation, and titration. A MINCO Reprint No. 104. 4p.

Bayly, I. L. and T. A. O'Neill. 1972a. Seasonal ionic fluctuations in a Typha glauca community. Eco1. 53:714-719.

Bayly, I. L. and T. A. O'Nei11. 1972b. Seasonal ionic fluctuations in a Pragmites communis community. Can. J. Bot. 50:2103-2109.

Berenyi, N. M. 1966. Soil productivity factors on the outer banks of North Carolina. Ph.D. thesis. North Carolina State University. $201 p$.

Boyd, C. E. 1969. Production, numeral nutrient absorption, and biochemical assimilation by Justicia americana and Alternanthera philoxeroides. Arch. Hydrobiol. 66:139-160.

Boyd, C. E. 1970a. Production and mineral accumulation and pigment concentrations in Typha latifolia and Scirpus americanus. Ecol. $51: 285-290$. 
Boyd, C. E. 1970b. Chemical analysis of some vascular aquatic plants. Arch. Hydrobiol. $67: 78-85$.

Boyd, C. E. 1971. The dynamics of dry matter and chemical substances in a Juncus effusus population. Amer. Mid. Natur. 86:28-45.

Boyd, C. E. and L. W. Hess. 1970. Factors influencing shoot production and mineral nutrient levels in Typha latifolia. Eco1. 51:296-300.

Boyd, C. E. and D. H. Vickers. 1971. Variation in the elemental content of Eichornia crassipes. Hydrobiol. 38:409-414.

Bray, J. R. 1962. Estimates of energy budgets for a Typha (cattail) marsh. Science 136:1119-1120.

Bray, J. R., D. B. Lawrence, and L. C. Pearson. 1959. Primary production in some Minnesota terrestrial communities for 1957. Oikos 10:38-49. Chabreck, R. H. 1972. Vegetation water and soil characteristics of the Louisiana coastal region. Louisiara State University. Agricultural Experiment Station Bu11. No. 664. 72p.

Daiber, F. C., J. L. Gallagher, and M. J. Sullivan. 1970. Tide marsh ecology and wildlife. 1969-1970. Annual Pittman-Robertson Report to Division of Fish and Wildlife. State of Delaware. 92p.

Darne11, R. M. 1961. Trophic structure of an estuarine community based on studies of Lake Pontchartrain. Fcol. 42:553-568.

Darnel1, R. M. 1964. Organic detritus in relation to secondary production in aquatic communities. Verh. Internat. Verein. Limno1. 15:462-470. Dietz, F. 1972. The enrichment of heavy metals in submerged plants. Presented at 6 th International Water Pollution Research Conference. $1-8$ 
Dixon, W. J., ed. 1968. BMD Biomedical Computer Programs. University of Calffornia Press, Berkeley and Los Angelos, California. 600p.

Durand J. B. and R. J. Nadeau. 1972. Water Resources in the Mullica River Basin. Part I. Biological evaluation of Mullica River. Great Bay Estuary. Water Resources Research Inst. 138p.

Environmental Protection Agency. 1969. Chemistry laboratory manual, bottom sediments. Federal Water Quality Administration. 43p.

Fox, D. L. 1950. Comparative metabolism of organic detritus by inshore animals. Ecol. 31:100-108.

Gerloff, G. C. and P. H. Krombholz. 1966. Tissue analysis as a measure of nutrient availability for the growth of angiosperm aquatic plants. Limnol. and Oceanogr. 11:529-537.

Gerloff, G. C. and F. Skoog. 1954. Cell contents of nitrogen and phosphorus as a measure of their availability for growth of Microcystis aeruginosa. Ecol. 35:348-353.

Good, R. E. 1965. Salt marsh vegetation, Cape May, New Jersey. Bul1. New York Acad. Sci. 10:1-11.

Gosselink, J. G. 1970. Growth of Spartina patens and $\underline{\text { s. alterniflora }}$ as influenced by salinity and source of nitrogen. Coastal Studies Bulletin No. 5. $97-110$.

Gossett, D. R. and W. E. Norris, Jr. 1971. Relationship between nutrient availability and content of nitrogen and phosphorus in tissue of the aquatic macrophyte, Eichornia crassipes (Mart.) Solms. Hydrobiol. $38: 15-28$.

Gray, A. J. and R. G. H. Bunce. 1972. The ecology of Morecambe Bay. IV. Soils and vegetation of salt marshes: a multi-variate approach. J. app1. Eco1. 9:221-234 . 
Harshberger, J. W. 1911. An hydrometric investigation of the influence of sea water on the distribution of salt marsh and estuarine plants. Proc. Amer. Phil. Soc. 50:457-497.

Hinde, H. P. 1954. The vertical distribution of salt marsh phanerograms in relation to tide levels. Ecol. Monogr. 24:209-225.

Huggett, R. J. and M. E. Bender. 1971. Sediment-heavy metal relationships in Rappahannock River sediments. Chesapeake Research Consortium, Inc. 232-241.

Jackson, C. R. 1952. Some topographic and edaphic factors affecting distribution in a tidal marsh. Quart. J. Florida Acad. Sci. 15: $137-146$.

Jervis, R. A. 1970. Primary production in a freshwater marsh ecosystem. Ph.D. Thesis. Rutgers State University. 59p.

Johnson, D. S. and H. H. York. 1915. The relation of plants to tide levels. Carnegie Inst. Wash. Pub. 非206. 162p.

Johnson, M. 1970. Preliminary report on species composition, chemical composition, biomass, and production of marsh vegetation in the upper Potuxent Estuary, Maryland. Chesapeake Biological Laboratory. Reference No. 70-130.

Kaushik, D. K. 1963. The influence of salinity on the growth and reproduction of marsh plants. Ph.D. Thesis. Utah State University. 123p.

Keefe, Carolyn W. 1972. Marsh production: A summary of the literature. Contr. in Mar. Sci. 16:164-181. 
Keefe, C. W. and W. R. Boynton. 1973. Standing crop of salt marshes surrounding Chincoteague Bay, Maryland-Virginia. Ches. Sci. 14: 117-123.

Keith, L. B. 1958. Some effects of increased soil salinity on plant communities. Can. J. Bot. 36:79-89.

Kirby, Jr., C. J. 1971. The annual net primary production and decomposition of salt marsh grass Spartina alterniflora Loisel. in the Barataria Bay estuary of Louisiana. Ph.D. Thesis. Louisiana State University. $74 p$.

Kontkanen, Paavo. 1957. On the delimitation of communities in research on animal communities. Cold Spring Har. Sym. Quant. Bio1. 22:373-378.

Lance, G. N. and W. T. Williams. 1967. A general theory of classification sorting strategies. I. Hierarchial System. Comput. J. 9:373-380.

Lathwel1, D. J., H. F. Mulligan and D. R. Bouldin. 1969. Chemical properties, physical properties and plant growth in twenty artificial. wildlife marshes. New York Fish and Game J. 16:158-183.

Macke, A. J. and I. A. Unger. 1971. The effects of salinity on germination and early growth of Puccinellia nuttalliana. Can. J. Bot. $49: 515-520$

Maye III, P. R. 1972. Some important inorganic nitrogen and phosphorus species in Georgia salt marsh. Environmental Resources Center. Georgia Institute of Technology. Report 0272, 60p. Mayer, Jr., F. L. and J. B. Low. 1971. The effect of salinity on widgeongrass. J. Wild1. Manage. 34:658-661.

Mooring, M. T., A. W. Cooper, and E. D. Seneca. 1971. Seed germination response and evidence for height ecophenes in Spartina alterniflora from North Carolina. Amer. J. Bot. 58:48-55. 
Morgan, M. H. 1961. Angiosperm production on a salt marsh. M.S. Thesis. University of Delaware. $34 \mathrm{p}$.

Nadeau, R. J. 1972. Primary production and export of plant materials in the salt marsh ecosystem. Ph.D. Thesis. Rutgers State University. $167 \mathrm{p}$

Odum, E. P. 1961. The role of tidal marshes in estuarine production. The N. Y. State Conservationist. 15:12-15.

Odum, E. P. and A. A. de la Cruz. 1967. Particulate organic detritus in a Georgia salt marsh estuarine ecosystem, p. 383-388. In G. H. Lauff (ed.) Estuaries. AAAS. Washington, D. C. Odum, H. T. 1960. Ecological potential and analogue circuits for the ecosystem. Amer. Sci. $48: 1-8$.

Odum, W. E. 1970. Utilization of the direct grazing and plant detritus food chains by the stripped mullet, Mugil cephalus, p. 222-240. In J. H. Steele (ed.) Marine food chains. University of California Press, Berkeley.

Palmisano, A. W. 1970. Plant community-soil-relationships in Louisiana coastal marshes. Ph.D. Thesis. Louisiana State University. 98p. Palmisano, A. W. and J. D. Newson. 1967. Ecological factors affecting occurrence of Scirpus olneyi and Scirpus robustus in Louisiana coastal marshes. 2lst Ann. Conf. Southeastern States Assoc. Game and Fish. Comm. p. 161-172.

Pearsall, W. H. and F. Gorham. 1956. Production ecology. I. Standing crops of natural vegetation. Oikos $7: 193-201$.

Pearsall, W. H. and P. J. Newbould. 1957. Production ecology. IV. Standing crops of natural vegetation in the subarctic. J. Eco1. 45:593-599. 
Phleger, F. 1971. Effects of salinity on growth of salt marsh grass. Ecol. 52:908-911.

Pigott, C. D. 1969. Influence of mineral nutrition on the zonation of flowering plants in coastal salt-marshes. p. 25-35. In I. H. Rorison (ed.) Ecological aspects of mineral nutrition. Blackwell Scientific Publications, Oxford.

Pomeroy, L. R. 1959. Algal productivity in salt marshes of Georgia. Limno1. and Oceanogr. 4:386-398.

Purer, E. A. 1942. Plant ecology of the coastal salt marsh lands of San Diego County, California. Fcol. Monogr. 12:82-111.

Ranwe11, D. S. 1964. Spartina salt marshes in southern England. III. Rates of establishment, succession, and nutrient supply at Bridgewater Bay, Somerset. J. Ecol. 52:95-105.

Ranwel1, D. S., E. C. F. Bird, J. C. E. Hubbard and R. E. Stabbings. 1964. Spartina salt marshes in Southern England. IV. Tidal submergence and chlorinity in Poole Harbour. J. Eco1. 52:627-641.

Reed, J.F. 1947. The relation of the Spartinetum glabra near Beauford, North Carolina to certain edaphic factors. Amer. Mid. Natur. $38: 605-613$.

Romig, R. F. and L. J. Cotnoir. 1971. Effect of oxygen on zonation, growth, and reproduction of salt marsh grasses. Second National Coastal and Shallow Water Research Conference 非192 (Abstr.). Smalley, A. E. 1958. The role of two invertebrate populations, Littorina irrorata and orchelimum fidicinum in the energy flow of a salt marsh ecosystem. Ph.D. Thesis. University of Georgia. $126 p$. 
Sokal, R. R. and P. H. A. Sneath. 1963. Principles of numerical taxonomy. W. H. Freeman. San Francisco. 359p.

Steele, R. G. D. and J. H. Torrie. 1960. Principles and procedures of statistics. McGraw-Hi11 Book Company, Inc., New York. 481 .

Steward, G. R., J. A. Lee, and T. O. Orebamjo. 1972. Nitrogen metabolism of halophytes. I. Nitrate reductase activity in Swaeda maritima. New Phytol. 71:263-267.

Stowe, W. C., C. Kirby, S. BrKich, and J. G. Gosselink. 1971. Primary production in a small saline lake in Barataria Bay. Louisiana Coastal Studies Bu11. No. 6. p. 27-37.

Stroud, L. M. and A. W. Cooper. 1969. Color-infrared aerial photographic interpretation and net primary productivity of a regularly flooded North Carolina salt marsh. M.S. Thesis. North Carolina State University at Raleigh. $86 \mathrm{p}$.

Teal, J. M. 1962. Energy flow in the salt marsh ecosystem of Georgia. Eco1. 43:614-624.

Ude11, H. F., J. Zarudsky, and T. F. Doheny. 1969. Productivity and nutrient values of plants growing in the salt marshes of the town of Hampstead, Long Island. Bull. of the Torrey Bot. Club. $96: 42-51$

Ungar, I. A. 1965. An ecological study of the vegetation of the Big Salt Marsh, Stafford County, Kansas. University of Kansas Sci. Bu11. 46:1-99.

Valiela, I., J. Wright, W. Kaplan, C. D'Avanzo Van Raalte, C. Krebs, N. Backus, N. McNelly, H. Ortins, E. Tea1, D. Masch, W. Saas, S. Holbrook, and D. Downing. 1972. Structure, function, and 
export of a salt marsh ecosystem subjected to nutrient enrichment, p. 26. In M. R. Carri Ker (ed.). A decade of whole organism biology. Spaulding Company, Randolph, Massachusetts.

Van Dyke, G. D. 1972. Aspects relating to emergent vegetation dynamics in a deep marsh, Northcentral Iowa. Ph.D. Thesis. Iowa State University. $162 \mathrm{p}$.

Van Dyne, G. M., W. G. Vogel, and H. G. Fisser. 1963. Influence of small plot size and slope on range herbage production estimates. Ecol. $44: 746-759$.

Waits, F. D. 1967. Net primary productivity of an irregularly flooded North Carolina salt marsh. Ph.D. Thesis. North Carolina State University at Raleigh. 113p.

Wass, M. L. and T. D. Wright, 1969. Coastal wetlands of Virginia Interim Report to the Governor and General Assembly. Virginia Inst. of Mar. Sci., Spec. Rept. in Applied Mar. Scil. and Ocean Eng. 非10.

Williams, R. B. and M. B. Murdoch. 1969. The potential importance of Spartina alterniflora in conveying zinc, manganese and iron into estuarine food chains. Prog. 2nd Natl. Symposium on Radioecology. p. 431-439. 
VITA

Irving Avrum Mendelssohn

Born in Scranton, Pennsylvania, August 10, 1947. Graduated

from Kingston High School, Kingston, Pennsylvania in June 1965.

Recelved a Bachelor of Arts degree from Wilkes College, Wilkes-

Barre, Pennsylvania in June 1969, with a major in biology. Taught

biology at the Fletcher Preparatory School in Rehoboth, Massachusetts, 1969-1970.

In February, 1971, the author entered the School of Marine Science, the College of William and Mary. 